AUDITOR STYLE AND COMMON DISCLOSURE DEFICIENCIES:

EVIDENCE FROM SEC COMMENT LETTERS

A Dissertation
presented to
the Faculty of the Graduate School
at the University of Missouri - Columbia
In Partial Fulfillment
of the Requirements for the Degree
Doctor of Philosophy
MATTHEW BAUGH
Dr. Elaine Mauldin, Dissertation Supervisor

December 2017 
The undersigned, appointed by the dean of the Graduate School, have examined the dissertation entitled

\section{AUDITOR STYLE AND COMMON DISCLOSURE DEFICIENCIES: EVIDENCE FROM SEC COMMENT LETTERS}

presented by Matthew Baugh,

a candidate for the degree of doctor of philosophy of Accountancy, and hereby certify that, in their opinion, it is worthy of acceptance.

Professor Inder K. Khurana

Professor Kyonghee Kim

Professor Elaine Mauldin

Professor Michael O’Doherty 
To my wife and children who loved, supported and sacrificed with me while I pursued my dreams. 


\section{ACKNOWLEDGEMENTS}

I thank the members of my dissertation committee, Elaine Mauldin (Chair), Inder Khurana, Kyonghee Kim and Michael O’Doherty for their helpful comments. I also thank Roy Schmardebeck for help constructing the Vector Space Model measure of comment letter similarity and workshop participants at the University of Missouri, Kent State University, Arizona State University, the University of Florida, Mississippi State University and Illinois State University. 


\section{TABLE OF CONTENTS}

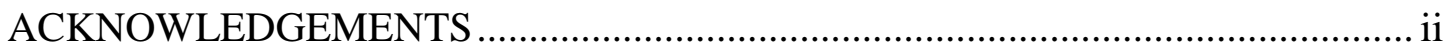

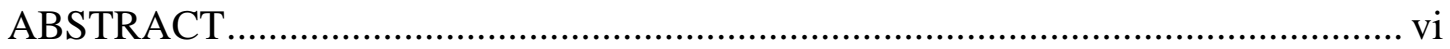

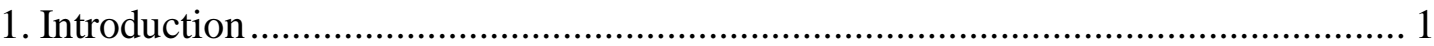

2. Background and Hypothesis Development............................................................ 8

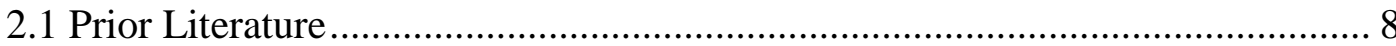

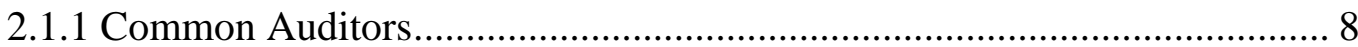

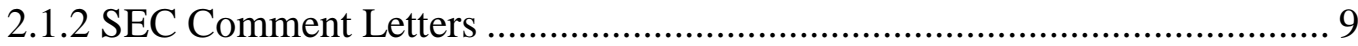

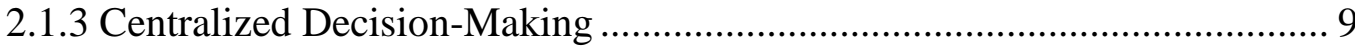

2.2 Audit Firm Decision Centralization....................................................... 11

2.3 SEC Comment Letter Review Process .......................................................... 12

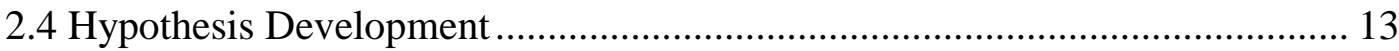

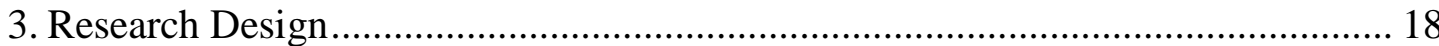

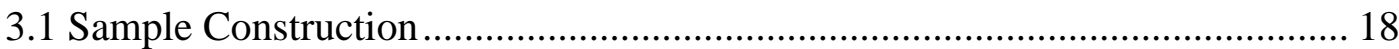

3.2 Measures of Comment Letter Similarity................................................... 19

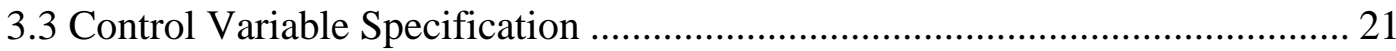

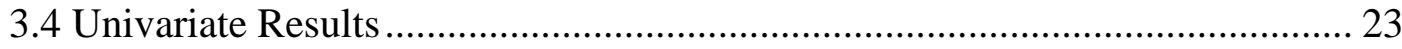

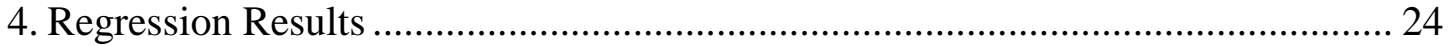

4.1 Auditor Style and SEC Comment Letter Similarity.................................... 24

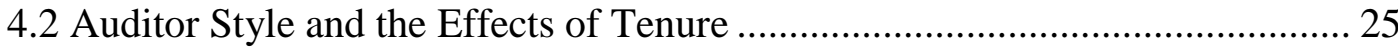




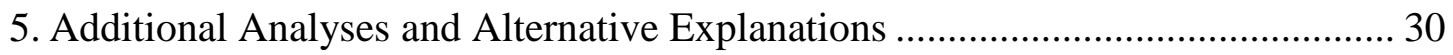

5.1 Auditor Style and SEC Comment Letter Similarity by Type ........................ 30

5.2 Comment Letter Selection ..................................................................... 32

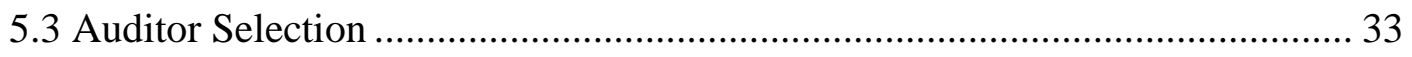

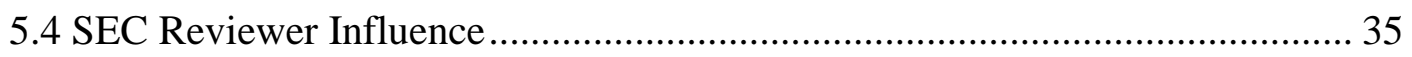

5.5 Auditor Style for Non-Big 4 Clients ....................................................... 38

5.6 Using the Most Recent Filing Referenced ............................................ 40

5.7 Auditor Style and Overall Disclosure Quality .......................................... 40

5.8 Auditor Style and Client Sophistication and Importance ............................. 43

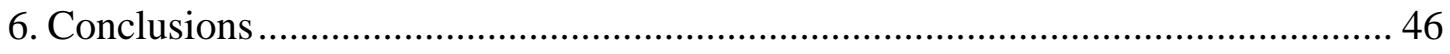

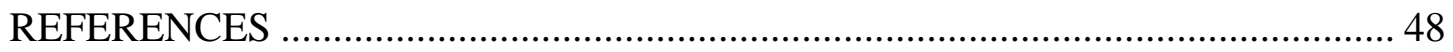

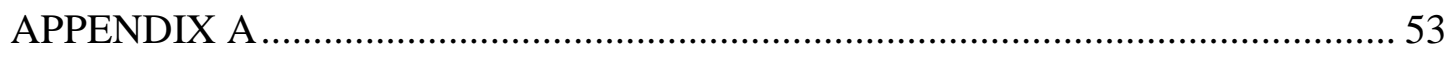

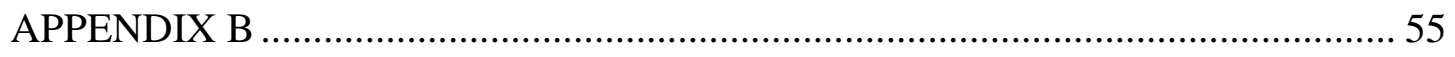

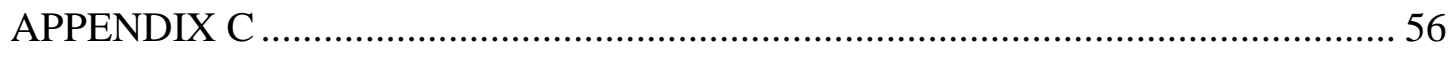

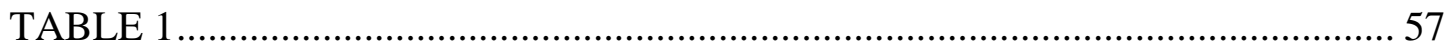

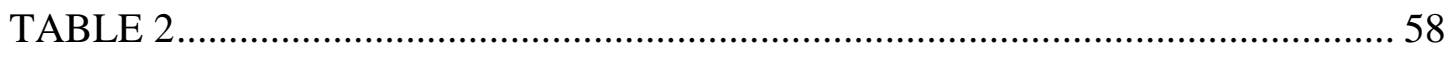

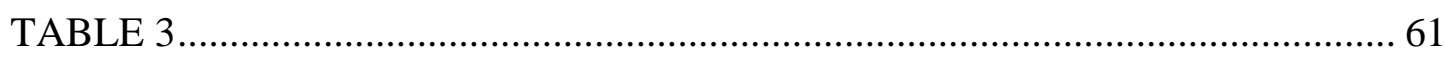

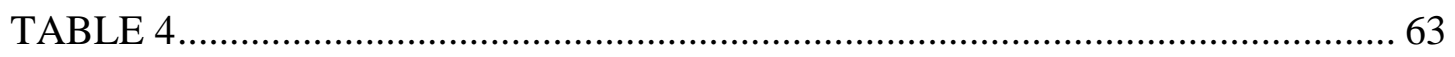

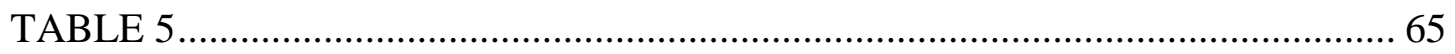


TABLE 6

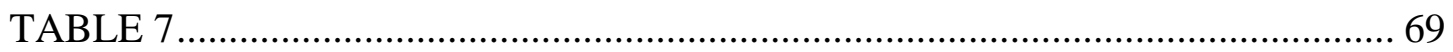

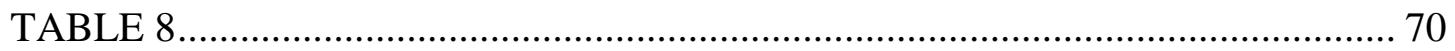

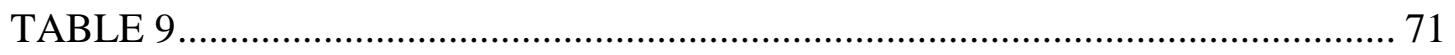

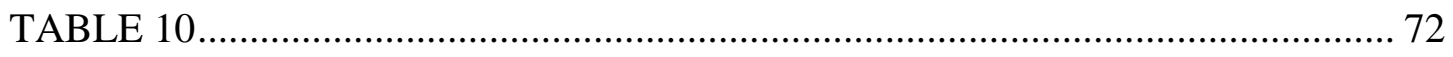

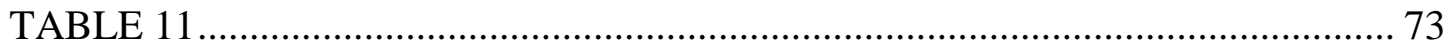

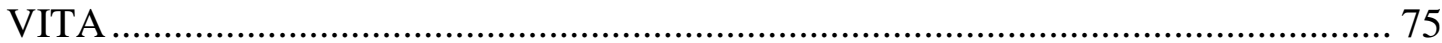




\begin{abstract}
Prior literature documents that auditor style increases financial statement comparability, implicitly making financial statements more useful to outsiders. Auditor style results from policies and procedures that centralize decision-making within the audit firm. A potential hazard of centralized decision-making is the propagation of decision errors throughout the entity. I predict, and find evidence to suggest, that auditor style is associated with a set of common disclosure deficiencies among clientele as measured by receipt of similar SEC comment letters. Clients also converge in both style and disclosure deficiencies as auditor tenure increases. Further, after changing auditors, clients appear to assume the style and disclosure deficiencies of the subsequent auditor. These results provide the first evidence that auditor style, while potentially a net benefit to users of the financial statements, has potential costs as well.
\end{abstract}




\section{Introduction}

The use of firm-wide policies and procedures in auditing firms is a form of centralized decision-making in which audit decisions are taken out of the hands of auditors (from the associate to the partner level) and placed in the hands of the policy writer. The merits of centralized and decentralized decision-making have been discussed extensively in the economics and management literature since Hayek (1945). A noted feature of centralized decision-making is it may lead to fewer decision errors, but when decision errors do occur they are global and propagate throughout the entity (Arcuri and Dari-Mattiacci 2010). In the context of the modern auditing firm, a myriad of audit decisions are made by the firm's methodology group, which is presumably best able to make such decisions. Decision errors, defined in this study as a disclosure position deemed deficient by a regulator, are likely minimized in this structure. However, errors that do occur may be global and propagate throughout the audit firm. This propagation would cause the error to be repeated at each audit client, thus potentially creating a set of disclosure deficiencies common to many clients of the auditor.

This study investigates whether auditor style, measured by the presence of a common audit firm, is associated with common disclosure deficiencies among audit clients, measured by receipt of similar SEC comment letters. I use the concept of auditor style developed by Francis, Pinnuck, \& Watanabe (2014), hereafter FPW, in which firm-wide, often proprietary, sets of policies and procedures direct the way audits are performed and lead to financial statements that are more comparable within an audit firm than across audit 
firms. ${ }^{1}$ These internal policies and procedures centralize decision making within the audit firm and potentially enhance the scope of decision errors.

Decision centralization, and therefore the potential for global level errors, occurs in virtually every aspect of the audit. I focus on decision errors related to financial statement disclosures, taken from SEC comment letters, because disclosures and the SEC comment letter setting have unique advantages that make them ideal for testing whether centralized decision-making is associated with global level errors. One, disclosure deficiencies can be attributed to the auditor in much the same way that deficiencies in the financial statements can. Auditing standards require the auditor to audit the footnote disclosures and review the management discussion and analysis (MD\&A) to ensure the discussion matches the financial statements/disclosures (AU Sections 550 and 551). Thus, auditors are responsible for providing assurance over the footnote disclosures (and to a lesser extent the MD\&A) in the same way they are responsible for assurance over the income statement, statement of cash flows and balance sheet. Relatedly, in the auditing literature, disclosure deficiencies are becoming a relatively well-accepted indicator of an audit deficiency (e.g., Glover, Hansen, \& Seidel 2015). Moreover, professional auditors in a survey listed SEC comment letters and enforcement actions (second only to restatements) as a useful indicator of audit deficiencies (Christensen et al. 2015). Thus, academics and practitioners alike generally accept disclosure deficiencies as indicators of a decision error on the part of the auditor. Two, comment letters are much more common than many other audit quality proxies. For

\footnotetext{
${ }^{1}$ Policies and procedures can take many forms and may not literally be called a "policy" or "procedure" in practice. For example, the accounts receivable audit program is an example of a policy with respect to how accounts receivable should be audited, although the word policy is never used. Policies and procedures also need not be formally written down. Informal company norms may represent a very rigid company policy. I use the term policies and procedures broadly to encompass all methods by which employee behavior is guided, constrained and standardized.
} 
a given three-year period (the amount of time it takes to ensure a firm is reviewed at least once by the SEC) anywhere from 63 to 77 percent of clients receive at least one comment letter (Cassell, Dreher, and Myers 2013). In contrast, the vast majority of clients go through any given three-year period without ever receiving a going concern opinion, an AAER, or announcing a restatement. Three, comment letters provide the researcher with very specific information about the issues that created the deficiency. Audit Analytics provides six issue types and 215 individual issue keys. This allows a researcher to identify common deficiencies in comment letters at a very detailed level. Four, comment letter reviews have the unique feature that reviewers examine the financial statement disclosures specifically to identify deficiencies. This intentional search for deficiencies has the benefit that it is likely to reveal common disclosure deficiencies even if auditor style has a net positive effect on audit/disclosure quality. ${ }^{2}$ For all these reasons, I operationalize common disclosure deficiencies (a type of decision error on the part of the auditor) by looking at the similarity of comment letters between audit clients.

This study is appealing in part because of the large body of theoretical and empirical literature on centralized decision-making supporting the link between auditor style and common disclosure deficiencies. Yet there remain credible reasons to expect no association between the presence of a common audit firm and the similarity of SEC comment letters. Even if the conceptual link between auditor style and common disclosure deficiencies is correct, operationalizing common disclosure deficiencies with similar SEC comment letters requires that comment letter reviewers are able to recognize the common disclosure deficiencies in a systematic, unbiased way. Concurrent work on SEC comment letters

\footnotetext{
${ }^{2}$ It is important to note I make no claim to the net benefit of auditor style. I merely claim that auditor style has costs in the form of common disclosure deficiencies.
} 
suggests that reviewers exhibit significant idiosyncratic effects (Baugh and Kim 2016). To the extent these idiosyncratic effects cause the results of the review to diverge from true common disclosure deficiencies related to auditor style, the idiosyncratic effects bias against finding results. The SEC comment letter review also encompasses the unaudited Management Discussion and Analysis (MD\&A) section of the 10-K disclosures. Ex ante, it is not obvious that auditor style effects should apply to the MD\&A, potentially biasing against finding results. And most importantly, the extant literature on auditor style suggests that style effects increase the comparability of financial statements among audit clients. This increased financial statement comparability (FSC) could increase audit efficiency and quality. ${ }^{3}$ As audit quality increases the potential for common disclosure deficiencies is constrained and all deficiencies become rarer and uncorrelated. Similarly, auditing firms centralize decisions about disclosure policy specifically to ensure that client disclosures comply with the relevant regulations, again constraining the potential for any kind of deficiency. ${ }^{4}$ These imply that strong auditor style effects may have no association, or even a negative association, with common disclosure deficiencies.

\footnotetext{
${ }^{3}$ Direct tests of the relationship between FSC and audit quality are rare. However, a number of indirect tests using related constructs where FSC is likely to be higher provide evidence consistent with the notion that increased FSC increases audit quality. The best examples of such indirect tests in archival research come from the industry expertise literature. Numerous studies (Balsam, Krishnan, and Yang 2003; Bell, Causholli, and Knechel 2015; Gul, Fung, and Jaggi 2009; Kwon, Lim, and Tan 2007; Reichelt and Wang 2010) find that auditing clients within an auditor's industry of expertise (where FSC is higher relative to clients outside one's industry of expertise) increases audit quality. Admittedly, it is difficult to separate the effects of specialized auditor knowledge and FSC, particularly because FSC within an industry may lower the cost of building specialized knowledge. The closest thing to a direct test of FSC and its relationship with audit quality comes from Brown \& Knechel (2016). They find that a text-based measure of disclosure compatibility (a potential proxy for FSC) is, under certain circumstances, associated with more accurate going concern opinions.

${ }^{4}$ Centralization is intended to ensure compliance with disclosure regulations by placing disclosure related decisions in the hands of in-house experts with the capability of interpreting complex and numerous disclosure standards.
} 
Nevertheless, I hypothesize and provide evidence to suggest that auditor style is associated with common disclosure deficiencies. I test this hypothesis by identifying all client-year observations for publicly traded Big 4 clients between 2004 and 2013 that received an SEC comment letter related to their annual filing. I then pair each of these client-year observations with all other observations from the same industry and fiscal year. ${ }^{5}$ Using a suite of three measures of comment letter similarity, I find that letter-pairs with the same audit firm have more similar comment letters. Clients with longer auditor tenure have the highest levels of comment letter similarity (i.e., client accrue their auditor's style and deficiencies over time). I also find that clients that change auditors between comment letters assume the disclosure deficiencies of the subsequent auditor (i.e., their letters become more similar to those of other clients of the subsequent auditor). Further, I find that the results are unlikely to be driven by a number of alternative explanations including client selection and SEC reviewer influence. I finally find that the results do not necessarily imply differences in aggregate disclosure quality among the Big 4 auditing firms, merely that they have unique sets of deficiencies that are similarly severe.

This study makes several contributions. The study contributes to the centralized/decentralized decision-making literature. While centralized/decentralized decision-making has been discussed in the financial accounting literature (Baiman, Larcker, and Rajan 1995; Baldenius and Reichelstein 2006; Robinson and Stocken 2013) it has not been discussed in the context of auditing, despite the high degree of centralization exhibited by most auditing firms. This study introduces the centralized versus decentralized

${ }^{5}$ FPW match client-years within industry to control for industry level effects that might influence accruals and earnings. I follow their design but also note that the SEC Division of Corporate Finance assigns comment letter reviews to particular offices by industry. Thus, pairing within industry also controls for various aspects of the review process which generates comment letters. 
debate to the auditing literature and provides evidence that auditing firms are subject to some of the same tradeoffs between centralization and decentralization as their publicly traded clients.

The study also contributes to the auditor style literature. When discussing the drawbacks of a principles based accounting standards regime, Kothari, Ramanna, \& Skinner (2010) argue that regulators need not worry about a lack of comparability inherent in principles based standards because audit firms will develop their own "working rules" which create comparability amenable to contracting and innovation. The auditor style literature to date has provided evidence consistent with this assertion (Francis, Pinnuck, and Watanabe 2013; Dhaliwal, Shenoy, and Williams 2016; Dhaliwal et al. 2016; Cai et al. 2016; Francis and Wang 2016). To the best of my knowledge, this is the first study to document that these auditor "working rules" have potentially negative consequences. That is, the auditor style that creates the comparability arises from centralized decision-making that propagates decision errors throughout an auditor's clientele. These results expand the auditor style literature to the realm of financial statement disclosure regulation, and provide a more complete picture of auditor style that encompasses both benefits and costs.

This study also sheds light on the poorly understood relationship between increased financial statement comparability and audit quality. In a related study, Brown \& Knechel (2016), hereafter BK, find that a textual measure of disclosure compatibility (a potential proxy for comparability) between a client and the pool of other clients from the same auditor has mixed associations with their measures of audit quality; restatements, abnormal 
accruals, and going concern opinion frequency and accuracy. ${ }^{6}$ I provide evidence that financial statement comparability (inferred from auditor style and the presence of a common auditor) is negatively associated with one dimension of audit quality, the presence of common disclosure deficiencies.

The results of this study may be of interest to audit firms and regulators. Audit firms interested in improving audit/disclosure quality need be aware that their firm-wide policies and procedures that give rise to auditor style also expose them to potential systemic deficiencies when those policies and procedures have flaws. Knowledge of systemic disclosure issues across audit firms may help the SEC more efficiently direct attention and limited resources during the comment letter review process. And the PCAOB has expressed general concern over the quality of disclosure auditing (Staff Audit Practice Alert No. 12, 2014) to which systemic disclosure deficiencies directly apply.

The rest of the paper proceeds as follows. Section 2 provides background information and develops the major hypotheses. Section 3 describes the study's research design. Section 4 presents the regression results. Section 5 discusses a number of additional analyses and alternative explanations and Section 6 provides concluding remarks.

6 The SEC comment letter setting differs from BK in that SEC employees review the quantitative portions of the financial statement disclosures in addition to the textual portions. Further, SEC comment letter reviews look explicitly for deficiencies, whereas the BK textual measure captures similarity in textual strengths as well as deficiencies. 


\section{Background and Hypothesis Development}

\subsection{Prior Literature}

\subsubsection{Common Auditors}

This study relates to three major literature streams. The first literature is that on auditor style, sometimes referred to as the common auditor literature. This literature began with FPW who documented that clients with the same auditor have more similar accruals structures and higher earnings covariation. These phenomena are attributed to the use of firm specific policies and procedures that standardize the accounting of clients within each firm. Subsequent work suggests that this enhanced comparability of financial reporting within a pool of audit clients facilitates merger transactions, relationship-specific investment, and lending (Cai et al. 2016; Dhaliwal et al. 2016; Dhaliwal, Shenoy, and Williams 2016; Francis and Wang 2016).

There is also a growing number of studies that document significant "auditor style" effects exhibited by audit partners (Chen and Wang 2016; Y. Wang, Yu, and Zhao 2015; Aobdia, Lin, and Petacchi 2015; Goodwin and Wu 2014; Knechel, Vanstraelen, and Zerni 2015; Gul, Wu, and Yang 2013). However, it is important to differentiate between auditor style at the firm level and auditor style at the partner level. At the partner level, auditor style is created by the idiosyncratic variation of each individual partner's decisions. Such idiosyncratic variation is constrained by the use of policies and procedures which standardize decisions by moving authority away from the partner to the policy maker. Therefore, it is generally expected that partner level auditor style is less prevalent among Big 4 firms where internal policies and procedures are robust (Gul, Wu, and Yang 2013; Chen and Wang 2016). However, auditor style at the firm level is created by, not 
constrained by, policies and procedures. Because policies and procedures are perceived to be more robust for Big 4 firms, auditor style at the firm level is generally expected to be more prevalent for Big 4 audit firms. It is auditor style at the firm level that is of interest in this study.

\subsubsection{SEC Comment Letters}

The second literature stream, related to the setting in which I test my hypotheses, is that on SEC comment letters. A large portion of this literature is dedicated to the determinants of comment letter receipt. Among many others characteristics, clients that are less profitable, more complex, have low accounting quality, or are in industries that require more subjective estimates are more likely to receive a comment letter (Cassell, Dreher, and Myers 2013; Boone, Linthicum, and Poe 2013; Hribar, Kravet, and Wilson 2013). Another major portion of the literature is dedicated to the consequences of comment letter receipt. Cassell et al. (2013) find that comment letter receipt is associated with financial restatements. Receipt of a SEC comment letter is also associated with decreases in institutional ownership (Gietzmann and Isidro 2013), increases in audit fees (Gietzmann and Pettinicchio 2013), increased insider trading (Dechow, Lawrence, and Ryans 2015) and subsequent improvement in disclosure quality (Bens, Cheng, and Neamtiu 2016; Hennes and Schenck 2014).

\subsubsection{Centralized Decision-Making}

The third related literature stream is that on centralized decision-making. The literature on centralized decision-making in economics and management is expansive and a comprehensive review is beyond the scope of this study. I instead highlight sub-streams of the literatures that are particularly relevant to the hypotheses at hand. 
The economics literature investigates how centralized decision-making affects decision quality. Much of this literature, beginning with Hayek (1945), highlights that quality decisions require quality information. Within an organization, many individuals will likely not possess the information required to make a high quality decision, particularly if the information required is specialized and difficult to communicate. Centralization of decision-making is one mechanism through which this information problem may be resolved. Decision power is centralized with an individual that possesses the requisite information. This person then makes one decision for all individuals, ensuring the requisite information is incorporated (Alavi and Leidner 2001; Grant 1996; Hayek 1945). However, Hayek (1945) suggests that in some circumstances centralized decision-making may harm decision quality. Individuals other than the central decision maker may have superior information, often because the central decision maker is somewhat removed from the tasks and details underlying the decision. This information may be difficult to communicate to the central decision maker and so it is not incorporated into the final decision, potentially creating decision errors.

Arcuri \& Dari-Mattiacci (2010) develop a model based on portfolio theory in which centralizing decision-making increases the scope and size of decision errors. The model illustrates why errors in a centralized environment are global and permeate throughout the entity. In their model, each individual decision is akin to an investment and the collective set of decisions is akin to an investment portfolio. Decentralization of decisions throughout an organization is similar to diversifying a portfolio across investment opportunities. While it is nearly certain some investments (decisions) will fail, the odds of a global, portfolio (organization) threatening failure are extremely low. However, with centralized decision- 
making the investments all go into the same opportunity. This portfolio assumes substantial risks related to non-diversification because if the chosen investment opportunity (decision) fails then the entire portfolio (organization) may fail with it.

The organizational management literature investigates how centralized decisionmaking influences the variance of firm performance. Sah \& Stiglitz (1991) develop a model in which the strengths and weaknesses of CEOs are magnified in a centralized environment where the CEO has more authority over operations. This magnification leads to a higher variance in organization performance even while mean performance and CEO ability remain constant. Consistent with this, Adams, Almeida, \& Ferreira (2005) find that powerful CEOs (i.e., ones with centralized decision-making authority) are associated with more variable stock returns. And Cheng (2008) find that clients with large boards of directors (i.e., low decision-making centralization) have less variable stock returns. The key insight from this literature, similar to Arcuri \& Dari-Mattiacci (2010), is that centralization magnifies the consequences of errors.

\subsection{Audit Firm Decision Centralization}

A critical assumption in ascribing the relationship between auditor style and common disclosure deficiencies to centralized decision-making is that audit firms do in fact centralize decision making throughout the firm via their policies and procedures. The following is a list of common audit activities that represent centralized decision-making with a formal policy/procedure or with a central decision making group:

- Consulting the national practice office before making certain significant decisions (e.g., asset impairment, issuing a going concern opinion, noting a material weakness).

- Formal meetings and coordination between industry/subject matter expert groups throughout the practice.

- Use of standardized sampling tools.

- Use of standardized work papers. 
- Use of standardized decision aids.

Particularly relevant to the comment letter setting is the use of disclosure checklists. A disclosure checklist is a decision aid, typically computerized, used by the engagement auditor to review the client's $10-\mathrm{K}$ disclosures for completeness. The use of disclosure checklists is widespread (Dowling and Leech 2007). All of the Big 4 firms have their own internally generated disclosure checklists. ${ }^{7}$ The checklists serve as the prime example of how decision-making is centralized in Big 4 audit firms with respect to the client's 10-K disclosures. The decision of whether or not the disclosures are complete is not left to the engagement auditor. It is decided by the creator(s) of the disclosure checklist, and those creators communicate their policy to the engagement auditor via the decision aid.

\subsection{SEC Comment Letter Review Process}

Section 408 of the Sarbanes Oxley Act (SOX) mandates that the SEC:

“...shall review disclosures made by issuers reporting under section 13(a) of the Securities Exchange Act of 1934 (including reports filed on Form 10-K), and which have a class of securities listed on a national securities exchange or traded on an automated quotation facility of a national securities association, on a regular and systematic basis for the protection of investors."

The section also mandates that the review take place no less frequently than once every three years. Within this three-year period the exact date of the review is at the discretion of the SEC. However, SOX Section 408 outlines factors the SEC should consider when scheduling reviews. These factors include:

- Whether an issuer filed a material misstatement.

- Whether an issuer has experienced significant volatility in its stock price.

- Whether an issuer has a large market capitalization.

- Whether an issuer has a large price to earnings ratio (for emerging companies).

- Whether an issuer's operations are central to any material sector of the economy.

\footnotetext{
${ }^{7}$ Promotional material for the EY disclosure checklist is available at: www.ey.com/GL/en/Issues/IFRS/IFRS-disclosure-checklists
} 
- Any other factor the SEC deems relevant.

The filing reviews are performed by personnel in the Division of Corporation Finance, a department within the SEC housed in Washington DC. Reviews are assigned to reviewers (who are mostly professional accountants and/or lawyers) based on the issuer's industry. ${ }^{8}$

When a reviewer finds a disclosure deficiency, the SEC sends a comment letter to the issuer outlining the disclosure issue(s). The letter generally asks the issuer to a) provide clarifying information to the SEC, b) provide clarifying disclosure in future financial statements, or c) in extreme cases, restate filed financial statements. The issuer is required to respond to the SEC within 10 days. The response may represent compliance with the SEC's request. The issuer may also respond with reasons they disagree with the SEC's requests. In the latter case, the SEC and issuer will discuss/negotiate the issues until the SEC is satisfied with the resolution. Subsequent communications may also occur because the issuer's compliance with the original request highlights new issues that require further elaboration.

Once the SEC is satisfied with the issuer's response to the comment letter they close the review. All correspondences between the issuer and the SEC are made publicly available within 20 days of the review closure. ${ }^{9}$

\subsection{Hypothesis Development}

Company policies and procedures that give rise to auditor style are a form of centralized decision-making that takes the power to make decisions relevant to a business task away

\footnotetext{
${ }^{8}$ Reviews typically involve more than one SEC reviewer. Often there is a staff level employee who develops a list of potential comments that are then approved by a senior level employee. In this study I refer to this group of personnel as the letter "reviewer".

${ }^{9}$ Prior to 2012 letters were made public within 45 days of review closure.
} 
from the frontline employee performing the task and places that power in the hands of the policy writer. The policy writer makes one decision for the entire company and communicates it through the company's policies and procedures manual. Task performers are expected to follow the directives of the policy writer, and exceptions to the policy often require authorization from management. The transfer of decision-making power away from the frontline employee to the policy writer is in most instances intentional. It allows for the specialized knowledge of the policy writer, which would be difficult to comminute to task performers, to influence how tasks are performed (Hayek 1945; Grant 1996; Alavi and Leidner 2001). In this way, the task performance is standardized and improved throughout the entity.

However, centralized decision-making is not a panacea. The standardization of decisions due to centralization can also lead to repetition of errors when the policy writer "gets it wrong". The task performers repeat the error as they follow the policy, which leads to errors that are global in scope and that permeate throughout the entity (Arcuri and DariMattiacci 2010). For a public accounting firm, a disclosure deficiency identified by the SEC is an indicator of a decision error with respect to the completeness and sufficiency of the $10-\mathrm{K}$ disclosures.

If centralized decision-making leads to global level errors, then auditor style may be associated with global disclosure deficiencies among the firm's clients. In other words, there may be a set of disclosure deficiencies that are common among a large portion of an audit firm's clientele. And the SEC comment letter review process is an ideal way of identifying such deficiencies. SEC comment letters are essentially a list of issues in the 
financial statement disclosures that a regulator believes may be insufficient/not in compliance with disclosure standards.

I note that the audited financial statement disclosures, like the financial statements themselves, are a joint work product of the auditor and client, and thus issues in an SEC comment letter may be an indictment of a client's disclosure policies and not the audit firm's policies per se. However, at a minimum the audit firm's policy allowed the disclosure crafted by the client to be filed with the SEC. In this way, the auditor's policies are at least partially responsible for any comment letter issues found in the audited disclosures. Further, the rise in popularity of audit firm disclosure checklists discussed in Section 2.3 suggests that auditors are in fact influencing client disclosure policies in a meaningful way. Thus, more similar comment letters between two clients are indicative of more similar disclosure deficiencies between the auditors that signed off on those financial statements. This reasoning leads me to my first hypothesis:

H1: Auditor style is associated with common disclosure deficiencies amongst audit clients as measured by more similar SEC comment letters.

Ascribing the association between auditor style and common disclosure deficiencies among clientele to centralized policies and procedures is dependent on the assumption that clients adopt the disclosure positions recommended by their auditor's policies and procedures. This assumption appears reasonable given recent and concurrent studies that document that textual components of the financial statement disclosures are more similar for clients with the same auditor (Brown and Knechel 2016; McMullin 2016) and the widespread use of disclosure checklists which provide a plausible mechanism for auditor style to influence $10-\mathrm{K}$ disclosures. However, it's unlikely that all audit clients have adopted the disclosure policies of their auditor (i.e., their auditor's style) equally. The 
degree to which a client has adopted their auditor's style may vary based on client-auditor tenure, the independence inherent in the auditor-client relationship, or the sophistication level of the client's internal financial statement preparers. In the case of client-auditor tenure specifically, auditors are unlikely to fully impose every policy and procedure to the fullest in the first years of an engagement. However, with each passing audit the auditor has another opportunity to move the client's reporting closer to the idealized standard represented by the policies and procedures. Consistent with this intuition, BK find that their measure of disclosure compatibility between a client and their auditor increases for up to five years after a client switches to the auditor. These results imply that auditors' style over disclosures accumulates as a function of auditor tenure. If two clients with the same auditor both have long auditor tenure, then they may both have more fully adopted the same auditor style and thus have converged toward the same policies and procedures. If this were true one would expect such clients to have the greatest similarities in auditor style, and with that style the greatest similarities in disclosure deficiencies. This reasoning leads me to the first part of my second hypothesis.

H2a: For those clients that have the same auditing firm, the commonality of disclosure deficiencies, as measured by more similar SEC comment letters, is higher among those clients that have long auditor tenure.

If tenure causes clients with the same auditing firm to converge in style and deficiencies, then the opposite may be true as well. That is to say long auditor tenure for clients at different auditing firms may cause them to diverge in style and deficiencies. If the Big 4 auditing firms' styles are meaningfully different, and clients that have long tenure have most fully adopted those styles, then clients with long tenure but different auditing 
firms should have the lowest levels of style and disclosure similarity. This reasoning leads me to the second part of my second hypothesis.

$H 2 b$ : For those clients that have different auditing firms, the commonality of disclosure deficiencies, as measured by more similar SEC comment letters, is lowest among those clients that have long audit tenure.

If auditors exhibit their own firm specific style, the question arises of what happens when a client changes auditors. Prior literature suggests that the client takes on the style of the new auditor. FPW find that abnormal accruals and earnings covariation become more similar to the clients of the subsequent auditor after changing. Similarly, BK find that after clients change audit firms their financial statement disclosures become more similar to the new auditor's pool of existing audit clients. If clients assume the style of the subsequent auditor upon changing, and auditor style is associated with common disclosure deficiencies, then it may be that clients also assume the set of disclosure deficiencies created by that style. This new set of disclosure deficiencies should result is comment letters, that are essentially a listing of disclosure deficiencies, that more closely match the comment letters of other clients of the subsequent auditor. This reasoning leads me to my third hypothesis:

H3: Audit clients assume the disclosure deficiencies of new auditors after auditor changes as measured by more similar SEC comment letters with the clients of the subsequent auditor. 


\section{Research Design}

\subsection{Sample Construction}

I begin constructing the main sample of comment letters using the Audit Analytics Commlett file. The sample includes comment letters issued for client fiscal years 2004 to 2013. I begin with fiscal year 2004 because comment letters issued prior to August 1, 2004 were not made public. I end the sample with fiscal year 2013 to allow sufficient time for the conversation to conclude and be made public. Each comment letter may have many observations on the Commlett file, one for each correspondence between the SEC and the audit client under review until the SEC closes the review. I follow Cassel et al. (2013) and remove comment letter conversations that appear to have incomplete data. This includes removing all observations for conversations that a) are not initiated by the SEC, b) do not contain a "No Further Comment" letter, c) contain only one letter from the SEC, d) contain less than three letters in total and e) have different first/last letter dates than the Audit Analytics Commlettconv file. Further, I restrict the sample to only those conversations that reference a company annual filing in the first letter and reference one of the six major issue types provided by Audit Analytics. ${ }^{10}$ I follow FPW and remove comment letters for clients without a Big 4 auditor, clients with less than $\$ 10$ million in total assets and letters referencing a fiscal year with a new auditor. After merging the Commlett file with the Audit Analytics Auditopin/Auditsox404 and Compustat Funda files, and screening for missing control variables, I have a final sample of 10,536 letters for 3,677 unique audit clients. The process used to create the comment letter sample is described in Table 1.

\footnotetext{
${ }^{10}$ After screening the Commlett file I compress it to one observation per comment letter by keeping only the first correspondence.
} 


\section{[Insert Table 1 Here]}

Table 2 Panel A presents descriptive statistics for the comment letter sample. All variables are defined in Appendix A.

\section{[Insert Table 2 Here]}

In order to test the similarity of two comment letters it is necessary to pair comment letter observations and compare their attributes. I follow FPW and create a panel of pairwise observations by pairing up all unique combinations of comment letters within a fiscal year and industry (2 digit SIC code). For example, if a given fiscal year and industry contained three letter observations (1,2 and 3) the resulting letter-pair observations would be Letter $1+$ Letter 2, Letter $1+$ Letter 3 and Letter $2+$ Letter 3 . The pairing process is

described in detail in Appendix B. Table 2 Panel B presents descriptive statistics for the letter-pairs sample.

I follow previous studies that use a pairs design (De Franco, Kothari, and Verdi 2011; Francis et al. 2009; Francis, Pinnuck, and Watanabe 2013) and create difference and minimum versions of the client-year control variables included in the comment letter sample (control variables are discussed in detail in Section 3.3). The suffix Diff in a variable's name denotes the difference variables which are the absolute value of the difference for that variable between the two comment letters in the letter-pair. The suffix Min denotes the minimum variables which are the minimum value of that variable between the two comment letters in the letter-pair.

\subsection{Measures of Comment Letter Similarity}

I construct three measures of comment letter similarity. 
The first two measures rely on the comment letter coding provided by Audit Analytics to identify issue keys (detailed codes for particular accounts and problems) or issue types (high level groups of similar issue keys) that appear in both letters of a pair. I follow Cassell et al. (2013) and use the six major issue types, and individual issue keys contained therein, provided by Audit Analytics to construct these two measures. The first measure, Similar Keys, is the number of issue keys (out of 215) that appear in both letters of a letter-pair, scaled by the total number of issue keys noted in both letters. The second measure, Similar Types, is the number of issue types (out of six) where both letters in a letter-pair have at least one issue key noted for that type, scaled by the total number of types in each letter that have at least one issue key noted. ${ }^{11}$ These measures range between zero and one. A higher value of Similar Keys/Types indicates more similar comment letters.

The third measure of comment letter similarity, Similar Text, measures the similarity of the textual content of the two comment letters in a pair using the Salton, Wong, \& Yang (1975) Vector Space Model (VSM). ${ }^{12}$ Prior literature in accounting has used this model to examine the similarity of 10-K disclosures (Brown and Tucker 2011; Brown and Knechel 2016; Peterson, Schmardebeck, and Wilks 2015). The VSM identifies unique words in a text string and coverts them into a vector of integers. Each element in the vector captures whether a particular word appears in the text string. For any two text strings, the angle between their VSM vectors represents the similarity of the text. The cosine of the angle is

\footnotetext{
${ }^{11}$ Cassel et al. (2013) identify six major issue types provided by Audit Analytics. They are Accounting Rule and Disclosure Issues, Internal Control Disclosure Issues, Management Discussion and Analysis Issues, Regulatory Filing Issues, Risk Factor Issues, and Other Issues. However, 80\% of letters have an issue identified for the Accounting Rule and Disclosure type. So I follow Cassel et al. (2013) and break this type down into four types, Core Issues, Non-Core Issues, Classification Issues and Fair Value Issues, to achieve more meaningful variation. This results in a total of nine major issues types for the Similar Types

${ }^{12}$ The full text of each comment letter is available on the Audit Analytics Commlett file.
} variable. 
then taken to create a value that ranges between zero and one. A value of zero represents text strings that have no words in common. A value of one represents identical text strings. When calculating Similar Text, I follow Peterson et al. (2015) and use word stemming and remove stop words and proper nouns. ${ }^{13}$ The exclusion of proper nouns is particularly important because occasional references to a client's auditor might otherwise create mechanical similarity between letter pairs with the same auditor. Like Similar Keys and Similar Types, a higher value for Similar Text indicates more similar comment letters. For ease of interpretation, all three measures of comment letter similarity are multiplied by 100 .

\subsection{Control Variable Specification}

The control variables used in the regression analyses are based off those factors found in Cassell et al. (2013) to be related to comment letter characteristics. ${ }^{14}$ Detailed definitions of all variables are provided in Appendix A.

Several factors are expected to be related to comment letter characteristics because Section 408 of SOX explicitly tells the SEC to consider them when scheduling/performing comment letter reviews (see the discussion of these considerations in Section 2.2). These factors include whether the client has filed a material restatement (ICMW and Concurrent Restatement), whether the client has experienced significant volatility in its stock price (High Volatility), and whether the client has a large market capitalization (LnMV).

A number of factors documented in prior research to be associated with financial reporting quality are also included. This is done because lower financial reporting quality is expected to be associated with lower disclosure quality, which in turn should generate

\footnotetext{
${ }^{13}$ Word stemming removes suffixes to obtain root words. Stop words include, for example, "the", it", this" or "that". Proper nouns include, for example, states, cities or names.

14 The one major exception is a suite of corporate governance variables. These variables are largely insignificant in Cassell et al. (2013) and are omitted for parsimony.
} 
more severe SEC comment letters. These financial reporting quality factors are firm age (Firm Age) and client profitability (Loss and ROA).

A client's bankruptcy risk (Altman Z) is included because financially distressed clients are less compliant with 8 -K reporting requirements which may spillover into less compliance with 10-K reporting requirements (Schwartz and Soo 1995; Schwartz and Soo 1996).

Factors associated with financial reporting complexity are included because more complex filings have greater opportunity for misapplication of $10-\mathrm{K}$ reporting requirements. These factors include the number of reporting segments (Segments), whether the client has experienced significant growth (Sales Growth), whether the client acquired another company (MNA), whether the client underwent restructuring activities (Restructure), whether the client obtained external financing (Ext Financing), and whether the client is in a high litigation risk industry (Litigation Risk).

The number of filings referenced in each comment letter (Filings) is included to control for the mechanical relationship between a broader comment letter review and its outcomes (e.g., more fillings reviewed may mechanically lead to identifying more issues).

Finally, the length of the relationship between the client and their auditor (Auditor Tenure) is included because auditor tenure influences audit and financial reporting quality (Geiger and Raghunandan 2002; Johnson, Khuran, and Reynolds 2002; Myers, Myers, and Omer 2003). Lower audit/financial reporting quality may lower disclosure quality, which should generate more severe comment letters. I do not include factors for auditor size because the sample is restricted to clients of Big 4 auditors. Thus, the sample selection controls for factors related to differing sizes of audit firms. 


\subsection{Univariate Results}

Table 2 Panel C presents descriptive statistics for the letter-pairs sample after splitting the sample on the value of Same Auditor. The panel also presents tests of the difference in means for each variable across the subsamples. The three measures of comment letter similarity are all higher for the Same Auditor $=1$ subsample and the differences are all statistically significant at the $\mathrm{p}<0.01$ level. This provides the first univariate evidence consistent with $\mathrm{H} 1$.

Table 3 Panel A presents Pearson correlations for the comment letter sample. Table 3 Panel B presents Pearson correlations between Same Auditor and the three measures of comment letter similarity using the letter-pairs sample. The correlations in Table 3 Panel B present additional univariate tests of $\mathrm{H} 1$.

\section{[Insert Table 3 Here]}

All three comment letter similarity measures are positively associated with Same Auditor at the $\mathrm{p}<0.01$ level ( $\mathrm{p}$ values un-tabulated). In total, the descriptive statistics provide evidence consistent with auditor style being associated with common disclosure deficiencies in the form of more similar comment letters. 


\section{Regression Results}

\subsection{Auditor Style and SEC Comment Letter Similarity}

To formally test H1 I estimate the following equation for the letter-pairs sample:

Comment Letter Similarity $_{\mathrm{i} 1, \mathrm{i} 2, \mathrm{t}}=\beta_{0}+\beta_{1} *$ Same Auditor $_{\mathrm{i} 1, \mathrm{i} 2, \mathrm{t}}+\beta_{\mathrm{k}} *$ Controls $_{\mathrm{i} 1, \mathrm{i} 2, \mathrm{t}}+\mathrm{v}+\varepsilon$

where the subscripts i1, i2, and tenote client 1, client 2 and time t, respectively. Comment Letter Similarity is one of three measures of comment letter similarity discussed in Section 3.2. Same Auditor is an indicator variable that equals one if both clients in the commentletter-pair have the same audit firm, and zero otherwise. Controls is a suite of control variables documented in prior literature (e.g., Cassell et al. 2013) to be associated with comment letter outcomes and discussed in detail in Section 3.3. $v$ is a vector of indicator variables to control for year and industry (2 digit SIC code) fixed effects. The model is estimated using OLS regressions with robust standard errors clustered by the gvkey combination of the two clients in the letter-pair (160,696 clusters). A positive coefficient on $\beta_{1}$ is consistent with auditor style being associated with common disclosure deficiencies in the form of more similar comment letters.

Table 4 presents the tests of $\mathrm{H} 1$ using equation (1), the letter-pairs sample and the three measures of comment letter similarity.

\section{[Insert Table 4 Here]}

The sample size in column (3) is slightly smaller because of missing comment letter text in Audit Analytics. With respect to H1, Same Auditor is positive and significant at the $\mathrm{p}<0.10$ level or better in all three columns. These results are consistent with $\mathrm{H} 1$ and 
suggest that the presence of a common auditor (auditor style) is associated with more similar comment letters (common disclosure deficiencies).

With regard to the economic interpretations of the estimated effects, the 0.157 coefficient estimate on Same Auditor in column (1) represents a 0.157 percentage point increase in the percentage of issue keys that show up in both letters. The coefficient on Same Auditor in column (2) can similarly be interpreted as a 0.047 percentage point increase in the percentage of issue types that appear in both letters. Relative to the mean value of Similar Keys (Similar Types) in Table 2 Panel B the coefficient on Same Auditor implies a $1.4 \%(0.5 \%)$ increase the average similarity of issue keys (types). While Similar Text has no such intuitive interpretation, the point estimate of 0.169 in column (3) equates to a $0.3 \%$ increase in textual similarity relative to Similar Text's mean in Table 2 Panel B. These values, admittedly, appear small. However, there are two major reasons that even these somewhat small effects should be of concern. One, given the size of the capital markets and the importance of financial statement disclosures to their function, even marginal improvements in disclosure quality may have large dollar value consequences for issuers and investors. Two, any systemic decision errors on part of the auditing firms should be of concern given the industry's history of catastrophic audit failures (e.g., Enron, Worldcom, Waste Management, etc.). To the extent these systemic disclosure deficiencies (and potentially other decision errors due to centralized decision-making) increase the chances of another of these catastrophic failures at all they represent something that should at least be acknowledged by the industry and academics alike.

\subsection{Auditor Style and the Effects of Tenure}


To test $\mathrm{H} 2 \mathrm{a}$ and $\mathrm{H} 2 \mathrm{~b}$ I estimate a variation of equation (1) with two subsamples derived from the main letter-pairs sample. In the analyses so far (and in subsequent analyses) I explicitly control for auditor tenure. But to test $\mathrm{H} 2 \mathrm{a}$ and $\mathrm{H} 2 \mathrm{~b}$ with respect to how auditor tenure influences style and disclosure deficiencies, I replace Auditor Tenure Diff and Auditor Tenure Min with Long Tenure. Long Tenure equals one if both clients in the letterpair have been with their auditor for five or more years. I choose five years because BK suggests that financial statement disclosure compatibility between a client and their auditor increases during the first five years of an engagement. I then estimate the following equation (2).

Comment Letter Similarity $_{\mathrm{i} 1, \mathrm{i} 2, \mathrm{t}}=\beta_{0}+\beta_{1} *$ Long Tenure $_{\mathrm{i} 1, \mathrm{i} 2, \mathrm{t}}+\beta_{\mathrm{k}} *$ Controls $_{\mathrm{i} 1, \mathrm{i} 2, \mathrm{t}}+\mathrm{v}+\varepsilon$

where Long Tenure is as defined above and all other variables are as defined in equation (1). I estimate equation (2) for two subsamples derived from the main comment letter-pair sample. The first subsample is only those letter-pairs that have the same auditing firm (i.e., Same Auditor $=1$ ). In this subsample, a positive coefficient on $\beta_{1}$ indicates that, consistent with $\mathrm{H} 2 \mathrm{a}$, within the pool of clients that have the same auditor, those clients that have had their auditor for a longer time have the highest levels of comment letter similarity. This is consistent with the idea that as auditor tenure increases these clients converge in disclosure style due to their auditor, and with the style converge in disclosure deficiencies. I use the second subsample of letter-pairs that do not have the same auditing firm (i.e., Same Auditor $=0)$ to test $\mathrm{H} 2 \mathrm{~b}$. In this second subsample a negative coefficient on $\beta_{1}$ indicates that, consistent with $\mathrm{H} 2 \mathrm{~b}$, within the pool of clients that have different auditors, those clients that have had their auditor for a longer time have the lowest levels of comment letter 
similarity. This is consistent with the idea that these clients are converging towards meaningfully different disclosure styles, and are thus diverging from one another in both disclosure style and deficiencies inherent in that style.

\section{[Insert Table 5 Here]}

Table 5 presents the estimations of equation (2) using the two subsamples of letterpairs and the three measures of comment letter similarity. Consistent with H2a, Long Tenure is positive and statistically significant at the $\mathrm{p}<0.10$ level or better in columns (2) and (3). These results suggest that within the group of clients that have the same auditor, those that have both had their auditor for five or more years have the highest level of comment letter similarity. Consistent with $\mathrm{H} 2 \mathrm{~b}$, Long Tenure is negative and significant at the $p<0.10$ level or better in columns (4) and (6). These results suggest that within the group of clients that have different audit firms, those clients that have long auditor tenure have the lowest levels of comment letter similarity. Taken together, columns (1) through (6) suggest that as auditor tenure increases clients converge (diverge) in style and deficiencies with clients from the same (different) audit firm.

\subsection{Auditor Changes and Assuming Disclosure Deficiencies}

To test $\mathrm{H} 3$ with respect to auditor changes I modify the main letter-pairs sample in a number of important ways. First, I limit the clients included in the comment letter sample to Switchers and Non-Switchers. Switchers are clients that have exactly two auditors associated with all their comment letters (i.e., they changed auditors between comment letters, but only once). Non-Switchers are clients that have exactly one auditor associated with all their comment letters. Switchers serve as a treatment group for the tests of $\mathrm{H} 3$ since they changed auditors and the properties of their comment letters can be observed both pre 
and post auditor change. The Non-Switchers serve as a control group because they never changed auditors and are thus exempt from the treatment of interest. I then pair Switcher comment letters to Non-Switcher letters from the same industry and year. However, Switcher letters are only paired to Non-Switcher letters that have the Switcher's subsequent auditor. This creates a panel of letter-pair observations where each observation includes one Switcher letter and one Non-Switcher, and the Non-Switcher letters always have the Switcher's subsequent auditor. This panel allows me to construct the variable Switch which equals one if the two clients in the modified letter-pair have the same auditor at time $t$ (i.e., the letters were written after the Switcher changed auditors), and zero otherwise. This process is described in detail in Appendix C. The Switch variable captures the degree to which the Switchers' comment letters become more similar to the letters of Non-Switchers at the Switcher's subsequent auditor. Using the Switch variable and the modified letter-pair sample I estimate the following equation:

Comment Letter Similarity $_{11, \mathrm{i}, \mathrm{t}, \mathrm{t}}=\beta_{0}+\beta_{1} *$ Switch $_{\mathrm{i} 1 \mathrm{i}, \mathrm{t}, \mathrm{t}}+\beta_{\mathrm{k}} *$ Controls $_{\mathrm{i} 1 \mathrm{i}, \mathrm{i}, \mathrm{t}}+v+\varepsilon$

where Switch is as defined above and all other variables are as defined in equation (1). A positive coefficient on $\beta_{1}$ indicates that, consistent with $\mathrm{H} 3$, clients assume the disclosure deficiencies of the subsequent auditor (as measured by increased similarity to the comment letters received by other clients of the subsequent auditor) after they switch to the subsequent auditor.

Table 6 presents the tests of $\mathrm{H} 3$ using equation (3), the modified letter-pair sample and the three measures of comment letter similarity.

[Insert Table 6 Here] 
Consistent with H3, Switch is positive and statistically significant at the $\mathrm{p}<0.05$ level or better in all three columns. These results suggest that audit clients assume the reporting deficiencies of their subsequent auditor, due to the subsequent auditor's style, after changing.

Tables 4, 5 and 6 all provide evidence consistent with hypotheses 1,2 and 3, respectively. This body of evidence suggests that a) auditor style is associated with common disclosure deficiencies, b) clients converge towards one another as auditor tenure increases and they more fully adopt their auditor's style/deficiencies and c) audit clients assume the style and deficiencies of new auditors. 


\section{Additional Analyses and Alternative Explanations}

\subsection{Auditor Style and SEC Comment Letter Similarity by Type}

Audit Analytics classifies issue keys into six broad types. The Accounting Rule type contains issues related to GAAP footnote disclosures which are explicitly audited by the auditor under AU 551. The MD\&A type contains issues related to the management discussion and analysis which is reviewed by the auditor under AU 550. It is possible, given the auditors varying degree of involvement in each of these types that the auditor style effect varies. It may be that the auditor's heavier hand in the GAAP related disclosures due to the auditing standards creates stronger style effects and thus more commonality in deficiencies. Or it may be that the detailed and voluminous disclosure regulations applicable to the Accounting Rule type, relative to the less regulated MD\&A, constrain meaningful differences in the policies and procedures of the Big 4 eliminating any unique style or disclosure deficiencies. To explore these possibilities I re-estimate equation (1) using variations of Similar Keys that count only the issue keys from a particular type. For example, for the Accounting Rule issue type the dependent variable equals the count of all issues keys from the Accounting Rule type that were present in both letters in the letterpair, scaled by the number of keys available in the Accounting Rule type. A positive coefficient on Same Auditor is consistent with auditor style being associated with common disclosure deficiencies for that issue type. Because the main analyses are conditional on the receipt of a comment letter (limiting the sample those letters that have at least one issue for any of the six types), I similarly limit the sample to those letters that have at least one key for a given type. That is to say that for the Accounting Rule measure of Similar Keys, all the letters have at least one Accounting Rule key noted. 


\section{[Insert Table 7 Here]}

Table 7 presents the results of these estimations. For brevity, the control variables have been omitted. Coefficients on Same Auditor have been standardized to facilitate comparisons across models. Same Auditor is positive and significant at the $\mathrm{p}<0.05$ level or better for both the Accounting Rule and MD\&A issue types. As far are their relative magnitudes, the two coefficients appear to be of similar size. The coefficient in column (2) for the MD\&A type (0.007) is slightly larger than that in column (1) for the Accounting Rule type (0.006), but in total it the MD\&A and GAAP related disclosures have similar systemic disclosure issues by audit firm.

For completeness, I also perform the same analyses for the other four issue types, Internal Control, Risk Factor, Regulatory Filing and Other. These results are reported in Table 7 columns (3) through (6). The coefficient on Same Auditor is only significant for the Other issue type. It's standardized magnitude is slightly smaller than that for Accounting Rule and MD\&A. It appears as if auditor style is not associated with common disclosure deficiencies for the Internal Control, Risk Factor and Regulatory Filing types. However, I note at least aspect of these additional issue types that may limit potential inferences. These issue types contain a large portion of nonrecurring disclosures items. Further, a lot of the nonrecurring items occur for reasons completely outside the auditor's control. For example, most of the Regulatory Filing type keys deal with registration statement issues and so are only applicable to those clients with equity issuances. Similarly, most of the Internal Control keys are only applicable if a client has an un-remediated internal control material weakness at year end. These nonrecurring disclosure issues induce noise in the sense that clients for auditor X may have been hit with a particular issue more 
often but weren't only because the issue was not applicable to them that year. It also reduces the sample size of the tests because these categories are much less frequently cited, whereas most letters have an Accounting Rule and MD\&A issue.

\subsection{Comment Letter Selection}

Comment letter recipients are not chosen randomly. SEC reviewers have discretion (within a three-year period) of when they review a client. Then within that pool of reviews certain clients are more likely to actually receive a letter than others (Cassell, Dreher, and Myers 2013). This potentially influences the documented results. Perhaps the documented results would not be present in the disclosure deficiencies of clients that did not receive a comment letter, if it were possible to observe them. Thus, the results of the study are generalizable only to the pool of clients with deficiencies noted by an SEC comment letter. However, I consider this limitation to be relatively minor for two reasons. One, a large proportion of Big 4 audit clients are included in the comment letter sample. For example, using the sample restrictions from this study, the Compustat/Audit Analytics universe for 2004 to 2013 has 4,825 unique clients. The comment letter sample in this study has 3,677 unique clients. Thus, generalizing to only the sample of clients that receive a comment letter still encompasses a majority of Big 4 clients. Two, the focus of the study is on the commonality of disclosure deficiencies given that a deficiency exists. The hypotheses make no mention of the frequency of deficiencies. In fact, I note in the hypothesis development that centralized decision-making often leads to better decisions implying fewer disclosure deficiencies overall. But when deficiencies exist, in a centralized environment, they are likely to permeate the entire entity. And the SEC comment letter setting is particularly adept at identifying clients where a deficiency exists. The SEC is required by law to review 
every public issuer at least once every three years with the explicit charge of finding disclosure deficiencies. As such, the process that selects firms into the comment letter sample actually identifies, with a reasonable level of accuracy, the exact firms of interest in this study.

\subsection{Auditor Selection}

The selection of audit firms by clients is not random. If a client's choice of audit firm is correlated with disclosure deficiencies (or in the extreme, clients knowingly choose auditors whose other clients have similar disclosure deficiencies) then this auditor selection, and not auditor style, may be driving my results.

The auditor changes analyses reported in Table 6 offer evidence that the main results are not driven by self-selection. If this were the case, there would be no reason to expect the Switch variable to ever load in Table 6. If clients merely chose auditors with a similar pool of deficiencies then the client should be equally close to the subsequent auditor's deficiencies before and after the change. Table 6 suggests that the client's noted deficiencies become more similar to the deficiencies of other clients of the subsequent auditor after the change, which can't be explained purely by endogenous matching. FPW find similar results in change style analyses that suggest the underlying construct of auditor style (which they also measure as the presence of a common auditor) is not wholly explained by client-auditor matching.

Further, as noted in FPW, the most salient selection decision documented in the empirical and theoretical audit literature is the decision between a Big 4 auditor and nonBig 4 auditor. Little evidence exists to suggest firms meaningfully select among the Big 4 
auditors. ${ }^{15}$ I hold the choice of Big 4 versus non-Big 4 auditor constant in this study by restricting the analyses to only clients of Big 4 firms.

However, one piece of recent evidence that does suggest that clients may meaningfully select among Big 4 audit firms is BK. BK find that Big 4 clients are more likely to switch to another Big 4 firm if their financial statement disclosures are less compatible with the disclosures of the other clients of their auditor. Further, the switching client is likely to switch to the Big 4 auditor whose existing clients have the most compatible financial statement disclosures. This appears to be evidence in favor of the matching explanation. However, BK also find that disclosure compatibility between a client and the audit firms' other clients increases with auditor tenure. Again, it is difficult to explain this post auditorchange effect as a product of client-auditor matching. If auditor style had no impact on financial statement disclosures, then there would be no reason to suspect that a new client should continue to get even more compatible after changing auditors. The only matching based explanation for this phenomenon would require the pool of other audit clients to keep turning over and becoming more compatible to the recently added client. This explanation would require a level of client turnover that is not observed in the data. Thus, even BK, which appears to be evidence in support of the client-auditor matching explanation, provides some evidence that auditor style effects are not purely a product of client-auditor matching.

\footnotetext{
15 The one exception to this is the choice between an industry expert auditor and a non-expert. Industry expert is not a documented determinant of SEC comment letter outcomes. However, to address the potential that industry expert selection is driving my results I both a) re-estimate the analyses dropping pairs where either auditor is an industry expert and b) re-estimate the analyses explicitly controlling for industry expertise. I define industry expertise as having $30 \%$ or more of client assets (I also use revenues) for an industry-year. In all cases I find my results are inferentially similar.
} 
Similar to BK, I also find in Table 5 that the auditor style effect in this study is a partial function of auditor tenure. Again, if clients merely match to a similar auditor, and auditors do not exhibit any style on the client, then auditor tenure should not influence the relationship between having a common auditor and the similarity of comment letters.

In summary, without experimental manipulation the possibility that client-auditor matching is influencing results can never be fully eliminated, and remains a potential limitation of the study. However, given the results of the switching analyses, the tenure analyses, the relative dearth of evidence suggesting clients meaningfully choose among Big 4 firms and the corroborating evidence from FPW and BK, client-auditor selection is likely not a significant issue in this study.

\subsection{SEC Reviewer Influence}

An SEC comment letter is a function of the financial statement disclosures under review and the SEC reviewer writing the letter. Auditor style only influences the former. Concurrent work suggests that individual reviewers exhibit significant idiosyncratic style effects on the outcomes of comment letter reviews (Baugh and Kim 2016). It may be necessary to control for the potential influence of individual SEC reviewers that may be affecting the results. To do this I create the variable Reviewer Diff which equals one if the letters in a letter-pair have a different reviewer. I obtain the reviewer identity from the signature line of the comment letter. In instances where multiple reviewers are noted in the signature line I use the first reviewer listed. In un-tabulated results, I add Reviewer Diff to the control variables for equations (1), (2a), (2b) and (3) and re-perform the analyses in Tables 4 through $6 .{ }^{16}$ The Reviewer Diff variable loads in the predicted direction (i.e.,

\footnotetext{
${ }^{16}$ I do not construct a Reviewer Min variable because there is no "minimum" value for two reviewers.
} 
having different reviewers is associated with less similar comment letters) at the $\mathrm{p}<0.01$ level in all twelve regressions. When using Similar Types as the measure of comment letter similarity the statistical significance for Same Auditor largely disappears after adding Reviewer Diff. However, the additional control has almost no effect on Same Auditor when using Similar Keys and Similar Text as the measures of similarity. This provides evidence that differences between individual reviewers are not driving the results.

Although controlling for the effects of individual reviewers does not meaningfully change the documented results, there is still the potential that reviewers collectively may influence comment letter review outcomes. For example, reviewers may intentionally look for certain issues among the clients of one audit firm and not others. This asymmetric review may create a self-fulfilling prophecy in which it looks as though a deficiency is more prevalent among audit firm A because the reviewers never checked for that deficiency at audit firms B, C and D. Such a phenomenon is difficult to rule out empirically because it has the same observable predictions as $\mathrm{H} 1$ and $\mathrm{H} 3$. However, searching for particular deficiencies among the clients of a specific auditor would require conspicuous coordination throughout the Division of Corporation Finance responsible for comment letter reviews. And while the SEC discloses few details about the review process, anecdotally, my experience with the SEC suggests that such targeting of deficiencies by auditor does not occur. Further, the self-fulfilling prophecy does not explain the auditor tenure results in Table 5. These results suggest that within an audit firm's clientele clients with long tenure have more fully adopted their auditor's style and with it their auditor's disclosure deficiencies. It may be plausible that the SEC would target particular issues by the client's 
auditor, it is not obvious though why the SEC would do this more for clients that had long auditor tenure. ${ }^{17}$

There is a more limited version of the self-fulfilling prophecy that is empirically testable. If SEC reviewers begin targeting other clients of the same auditor after they have discovered an issue then there may be a temporal link between the probability a client has an issue noted and whether said issue had been previously noted. To test this temporal version of the self-fulfilling prophecy I use logistic regression to estimate the following equation:

$$
\text { Issue Ind }_{\mathrm{i}, \mathrm{t}}=\beta_{0}+\beta_{1} * \text { Prior Issue Auditor } \mathrm{i}_{\mathrm{i}, \mathrm{t}} \beta_{\mathrm{k}} * \text { Controls }_{\mathrm{i}, \mathrm{t}}+\mathrm{v}+\varepsilon
$$

where subscripts $\mathrm{i}$ and $\mathrm{t}$ denote client and time, respectively. Issue Ind is an indicator variable that equals one if a comment letter has at least one issue key noted for a particular issue type provided by Audit Analytics, and zero otherwise. Prior Issue Auditor is an indicator variable that equals one if, in the prior 365 days, another comment letter for a client with the same industry and same audit firm had an issue noted for the given type, and zero otherwise. Controls are the client-year versions of the control variables in equation (1) and $v$ is a vector of indicator variables to control for year and industry (2 digit SIC code) fixed effects. I estimate the model using the comment letter sample from Table 2 Panel A. ${ }^{18}$ A positive coefficient on $\beta_{1}$ in equation (4) is consistent with SEC comment

${ }^{17}$ SEC comment letter reviews do have "seasons" in which particular issues are given higher focus. However, this is not the same as the self-fulling prophecy. So long as the search for the targeted issue is applied equally across audit firms then the season cycle would not create the documented results. For a given issue under review, a client would still actually have to have the targeted deficiency in order for it to be noted, and if a client did not have the deficiency noted it could be assumed the client did not actually have the deficiency. This still allows for the identification of common disclosure deficiencies. What the season cycle may do is shrink the set of common deficiencies likely to be discovered, potentially biasing against finding results.

${ }^{18}$ Fiscal year 2004 is removed from this panel so that all observations have time for a prior comment letter. 
letter reviewers being more likely to identify an issue type after a client with the same industry and audit firm had an issue of the same type.

\section{[Insert Table 8 Here]}

Table 8 presents the results of estimating equation (4) for each of the six issue types provided by Audit Analytics. For brevity, the control variables have been omitted. Prior Issue Auditor is not statistically positive for any of the issue types. Further, Prior Issue Auditor is statistically negative at the $\mathrm{p}<0.10$ level for the Other issue type. These results provide no evidence in favor of the temporal self-fulfilling prophecy. In fact, the results in column (6) suggest that clients are less likely to receive a letter for a particular issue type after someone in their industry and with their audit firm received a letter with that issue type. This result is consistent with concurrent work that suggests clients modify their 10$\mathrm{K}$ disclosures in response to comment letters issued to peer clients (Brown, Tian, and Tucker 2015). I note that this phenomena would have the exact opposite effect of the temporal self-fulfilling prophecy, substantially biasing against finding similar comment letters among clients with the same auditor.

\subsection{Auditor Style for Non-Big 4 Clients}

FPW predict that the influence of the policies and procedures that give rise to auditor style will be stronger among Big 4 clients than non-Big 4 clients. This is because Big 4 firms have greater capacity to create, and need for, centralized policies that apply US GAAP uniformly across clients. ${ }^{19}$ Consistent with this notion, FPW find only mixed and weak evidence of auditor style effects among non-Big 4 clients using abnormal accruals

\footnotetext{
19 The Big 4 firms' increased capacity comes from their ability to absorb the fixed costs of developing policies and procedures and their access to experts capable of developing such policies and procedures. Their increased incentive comes from their distributed geographical structure and heightened litigation risk which increase the need for quality control measures such as detailed policies and procedures manuals.
} 
similarity and earnings covariation. If policies and procedures have a greater influence on how Big 4 firms perform audits, then it follows that the similarity of Big 4 client comment letters should be greater than that of non-Big 4 clients. This is a difficult intuition to test in the comment letter setting because relatively few non-Big 4 clients receive comment letters. Further, approximately $30 \%$ of the smallest non-Big 4 audit firms that exist in the intersection of Audit Analytics and Compustat never have a client that receives a comment letter. Thus, the non-Big 4 clients and firms in the comment letter setting are larger with more incentives to standardize than those in a broader setting such as FPW. Nevertheless, I test this intuition by estimating equation (1) for a panel of letter-pair observations constructed from non-Big4 clients that received SEC comment letters.

\section{[Insert Table 9 Here]}

Table 9 presents the tests of the intuition that the auditor style effect, and thus the commonality of disclosure deficiencies, should be weaker for non-Big 4 letter-pairs using equation (1), the non-Big 4 letter-pairs sample and the three measures of comment letter similarity. For brevity, the control variables have been omitted. Similar to FPW, I find only weak and mixed evidence of auditor style effect/common disclosure deficiencies among non-Big 4 clients. The coefficient on Same Auditor is positive and significant at the $\mathrm{p}<$ 0.05 level in column (3). However, it is insignificant in column (2) and it is negative and significant at the $\mathrm{p}<0.10$ level in column (1). These results do not provide consistent evidence for, and provide some evidence against, the existence of an auditor style effect among non-Big 4 auditing firms. This generally supports the notion that auditor style effects, and the common disclosure deficiencies they engender, are stronger among the Big 4 auditing firms. 


\subsection{Using the Most Recent Filing Referenced}

A small percentage of letters reference more than one annual filling. When merging comment letters to Compustat and the Audit Analytics Auditopin file I use the Compustat/Audit Analytics fiscal year that matches the fiscal year of the oldest annual filing referenced in the comment letter. I test the robustness of this design choice by merging comment letters to Compustat/Audit Analytics using the fiscal year of the most recent annual filing referenced in the comment letter. In un-tabulated results I find the documented results are inferentially similar.

\subsection{Auditor Style and Overall Disclosure Quality}

The empirical results thus far suggest that the Big 4 auditing firms have unique disclosure styles that pass systemic disclosure deficiencies to their clients. This is not the same as suggesting that the clientele of the Big 4 auditing firms have, in aggregate, differing disclosure quality. It is possible that each of the auditing firms has unique sets of deficiencies that are, in aggregate, of similar severity. One potential way to measure overall disclosure quality is the likelihood of receiving an SEC comment letter. To test whether the Big 4 auditing firms have different aggregate levels of disclosure quality, as measured by the likelihood of receiving an SEC comment letter, I estimate the following logistic equations using the full sample of Compustat Big 4 client-year observations: ${ }^{20}$

$$
\begin{gathered}
\text { Letter }_{\mathrm{i}, \mathrm{t}}=\beta_{0}+\beta_{\mathrm{k}} * \text { Control }_{\mathrm{i}, \mathrm{t}}+\mathrm{v}+\varepsilon \\
\text { Letter }_{\mathrm{i}, \mathrm{t}}=\beta_{0}+\beta_{\mathrm{k}} * \text { Controls }_{\mathrm{i}, \mathrm{t}}+\mathrm{v}+\text { Auditor Fixed Effects }+\varepsilon^{-}
\end{gathered}
$$

${ }^{20}$ To construct this panel I use the sample selection process as described in Table 1 except that clientyears are not required to have an SEC comment letter. Therefore, any screens related to comment letter characteristics are ignored. 
where Letter equals one if the client receives an SEC comment letter referencing year t, and zero otherwise. Controls are the client-year versions of control variables used in equation (1), minus those control variables directly related to comment letter characteristics. $v$ is a vector of indicator variables to control for year and industry (2 digit SIC code) fixed effects. Auditor Fixed Effects is a set of indicator variables that capture which of the Big 4 auditing firms the client engaged in year t. Auditor Fixed Effects capture whether clients of each Big 4 auditing firm, on the whole, have meaningfully different likelihoods of receiving an SEC comment letter. I perform a chi ${ }^{2}$-test for the joint significance of the auditor indicator variables to test whether the probability of receiving an SEC comment letter is statistically different among the Big 4 firms.

\section{[Insert Table 10 Here]}

Estimations of equations (5a) and (5b) are reported in Table 10 columns (1) and (2), respectively. Not only are the pseudo $\mathrm{R}^{2} \mathrm{~s}$ in columns (1) and (2) the same to three decimal places (suggesting the auditor fixed effect does not meaningful improve model performance) but the $\mathrm{chi}^{2}$ statistic for the auditor fixed effect is insignificant with a chi ${ }^{2}$ statistic ( $\mathrm{p}$ value) of 4.07 (0.254). These results do not provide any evidence to suggest that the Big 4 firms have meaningfully different likelihoods of receiving SEC comment letters.

But the likelihood of receiving a comment letter is not the only dimension on which clients of the Big 4 firms may differ in disclosure quality. Though all firms may be equally likely to receive a letter, letters of particular clienteles may be more severe. To test this possibility I estimate the following equations using the comment letter sample from Table 2 Panel A:

$$
\text { Severity }_{\mathrm{i}, \mathrm{t}}=\beta_{0}+\beta_{\mathrm{k}} * \text { Controls }_{\mathrm{i}, \mathrm{t}}+\mathrm{v}+\varepsilon
$$




$$
\text { Severity }_{\mathrm{i}, \mathrm{t}}=\beta_{0}+\beta_{\mathrm{k}} * \text { Controls }_{\mathrm{i}, \mathrm{t}}+\mathrm{v}+\text { Auditor Fixed Effects }+\varepsilon
$$

where Severity is one of four measures designed to capture the extent of issues contained in a comment letter and the costs of remediating them; Keys is the number of detailed issue keys (out of 215) identified in the letter, Types is the number of issue types (out of six) in the letter with at least one key noted, Rounds is the number of communications between the client and SEC before the conversation is closed, and Days is the number of days between the first and last letter in the conversation. Controls are the client-year versions of control variables used in equation (1) and all other variables are as defined for equations (5a) and (5b). Auditor Fixed Effects again capture aggregate differences in disclosure quality among clients of the Big 4 firms and I perform an F-test for the joint significance of the auditor indicator variables.

Estimations of equations (6a) and (6b) are reported in Table 10 columns (3) through (10). The improvement in model performance by adding auditor fixed effects is negligible (i.e., the adjusted $\mathrm{R}^{2} \mathrm{~s}$ are generally the same out to three decimal places). Similarly, the $\mathrm{F}$ stats for the joint hypothesis on the auditor indicator variables are all statistically insignificant except for columns (9) and (10) when Days is the dependent variable. This suggests that one of the costs associated with severe comment letters, the time invested in crafting responses, does differ meaningfully among the Big 4 firms. However, I note that the days it takes to resolve a comment letter conversation is a function of both the severity of the original comment letter and other idiosyncratic determinants of the time/preparation taken to respond to the SEC. Auditors are often heavily involved in the crafting of responses to the SEC. The auditor fixed effect on Days may be indicative of firm level 
styles in the time given to crafting responses as much as the severity of the original comment letter itself.

These results broadly suggest that a) clients of any particular audit firm are no more likely to receive a comment letter, and b) clients of a particular audit firm receive letters no more severe than clients of any other firm. The only exception is Days in columns (9) and (10) which suggests that clients of a particular auditor firm do take a distinct number of days to resolve a comment letter conversation. However, the results do not support the broader idea that the major auditing firms have, in aggregate, substantially different disclosure quality. The results in Tables 4 through 6 should then be interpreted to mean that the Big 4 auditing firms have unique sets of disclosure deficiencies that they pass to their clients, although each of those deficiency sets appear to be equally severe.

\subsection{Auditor Style and Client Sophistication and Importance}

In Section 4.2 I note that clients of a particular auditor may not have equally adopted their auditor's style. The results in Table 5 suggest those clients that have longer auditor tenure have more fully adopted this style and with it the style's deficiencies. It is also plausible that client sophistication and/or independence may influence the relationship between auditor style (as measured by the presence of a common auditor) and common disclosure deficiencies (as measured by more similar SEC comment letters). Those clients that have more robust financial statement preparation units and/or more complex/idiosyncratic business practices (i.e., are more sophisticated) may not lean on their auditor as much in preparing financial statement disclosures and thus may have adopted their auditor's style less. Therefore the presence of a common auditor among these firms may not engender the same disclosure similarities, and with them deficiencies. 
Similarly, if the adoption of auditor style creates conflicts between the auditor and client then those clients that represent independence threats may have adopted the style less. That is to say that as auditors attempt to get unwilling clients to conform to their disclosure policies, they may be more likely to acquiescence to an important client and thus depart from the style, making the presence of a common auditor less meaningful for important clients. I explore both of these possibilities in this section.

\section{[Insert Table 11 Here]}

To test whether client sophistication influences the relationship between auditor style and common disclosure deficiencies, I estimate equation (1) for two subsamples split on the median value of a proxy for client sophistication. ${ }^{21}$ I proxy client sophistication using client size (total assets), reasoning that larger clients are more likely to have robust financial statement preparation units and engage in more complex/idiosyncratic business practices. The estimations of equation (1) for the subsamples are reported in Table 11 Panel A. Counter to the stated intuition, the association between auditor style and common disclosure deficiencies is present in the sophisticated/large client subsample and disappears completely in the unsophisticated/small client subsample.

To test whether client importance influences the relationship between auditor style and common disclosure deficiencies, I estimate equation (1) for subsamples split on the median value of one of three proxies for client importance. The three proxies for importance are based on ratios of client fees to the total fees for the client's audit office. For example, in Table 11 Panel B importance is measured as the client-year audit fee divided by all audit fees collected that year by the client's audit office. Panel C uses similar logic but non-audit

${ }^{21}$ When conducting median splits with a panel of pairwise observations I require that both of the observations in the pair be above (below) the sample median to make into the above (below) subsample. 
fees instead of audit fees, and in Panel D I use total fees. Across panels Panels B through $\mathrm{D}$ the association between auditor style and common disclosure deficiencies appears in both the important and unimportant subsamples. The association is at its weakest in the Panel D unimportant subsample (where only one measure of comment letter similarity rejects the null hypothesis) and at its strongest in the Panel B important subsample (where all three measures of similarity reject the null). But generally, the results do not provide consistent evidence that the association between auditor style and common disclosure deficiencies is weaker/stronger for important/unimportant clients. 


\section{Conclusions}

Motived by the expansive economics and management literature on centralized decision-making (Alavi and Leidner 2001; Arcuri and Dari-Mattiacci 2010; Graham, Harvey, and Puri 2015; Grant 1996; Hayek 1945; Sah and Stiglitz 1991), in this study, I document that auditor style, measured by the presence of a common auditor, is associated with common disclosure deficiencies, measured by receipt of similar comment letters. Letter-pairs with the same auditor are more similar in terms of the issue keys and types identified in the letter and the text the SEC reviewer uses to describe those issues. Comment letter similarity is stronger amongst those clients with long auditor tenure. And clients that change auditors between comment letters assume the disclosure deficiencies of the subsequent auditor, which helps to rule out a number of other plausible explanations for the results.

To date, the auditor style literature has highlighted the increased financial statement comparability that it creates and the benefits of that comparability (Francis, Pinnuck, and Watanabe 2013; Francis and Wang 2016; Dhaliwal, Shenoy, and Williams 2016; Dhaliwal et al. 2016; Cai et al. 2016). And the broader literature on financial statement comparability lauds comparability's benefits with little discussion of its costs. ${ }^{22}$ I document in this study that at least one source of financial statement comparability, auditor style, has notable costs. I make no statement about the net benefits of auditor style and financial statement comparability. I merely state that auditor style, possibly even financial statement

\footnotetext{
${ }^{22}$ Some of this literature focuses on the benefits of financial statement comparability within the United States (De Franco, Kothari, and Verdi 2011; DeFond and Hung 2003). However, much of it focuses on the benefits of financial standard harmonization around IFRS which increases financial statement comparability (DeFond et al. 2011; Ozkan, Singer, and You 2012; Yip and Young 2012; Brochet, Jagolinzer, and Riedl 2013; C. Wang 2014; Yu and Wahid 2014; Fang, Maffett, and Zhang 2015; Young and Zeng 2015).
} 
comparability, is not a panacea. At least as far as auditor style is concerned, the comparability arises from centralized decision-making, which has predicable negative consequences.

It is important that academics develop refined and nuanced conceptions of constructs, like auditor style, that reflect the greyness of the real world. Such understanding can only aid in the expansion of knowledge in our field. This study pushes the literature a step toward that goal with respect to auditor style. Further, the results of this study beg for more research on the negative consequences of auditor style and financial statement comparability itself. What are the potential costs? When are they greatest? When are they mitigated? And most importantly, under what circumstances may they eclipse the benefits? 


\section{REFERENCES}

Adams, Renée B., Heitor Almeida, and Daniel Ferreira. 2005. "Powerful CEOs and Their Impact on Corporate Performance." Review of Financial Studies 18 (4). Oxford University Press: 1403-32.

Alavi, Maryam, and Dorothy E. Leidner. 2001. "Review: Knowledge Management and Knowledge Management Systems: Conceptual Foundations and Research Issues." MIS Quarterly 25 (1): 107.

Aobdia, Daniel, Chan-Jane Lin, and Reining Petacchi. 2015. "Capital Market Consequences of Audit Partner Quality." The Accounting Review 90 (6). American Accounting Association: 2143-76.

Arcuri, Alessandra, and Giuseppe Dari-Mattiacci. 2010. "Centralization versus Decentralization as a Risk-Return Trade-Off." The Journal of Law \& Economics 53 (2): 359-78.

Baiman, Stanley, David F. Larcker, and Madhav V. Rajan. 1995. "Organizational Design for Business Units.” Journal of Accounting Research 33 (2): 205.

Baldenius, Tim, and Stefan Reichelstein. 2006. "External and Internal Pricing in Multidivisional Firms." Journal of Accounting Research 44 (1). Blackwell Publishing Inc: $1-28$.

Balsam, Steven, Jagan Krishnan, and Joon S. Yang. 2003. "Auditor Industry Specialization and Earnings Quality.” AUDITING: A Journal of Practice \& Theory 22 (2): 71-97.

Baugh, Matthew, and Kyonghee Kim. 2016. The Effect of SEC Reviewers on Comment Letters and Financial Reporting Quality.

Bell, Timothy B., Monika Causholli, and W. Robert Knechel. 2015. "Audit Firm Tenure, Non-Audit Services, and Internal Assessments of Audit Quality." Journal of Accounting Research 53 (3): 461-509.

Bens, Daniel A., Mei Cheng, and Monica Neamtiu. 2016. "The Impact of SEC Disclosure Monitoring on the Uncertainty of Fair Value Estimates." The Accounting Review 91 (2). ap: 349-75.

Boone, Jeff P., Cheryl L. Linthicum, and April Poe. 2013. "Characteristics of Accounting Standards and SEC Review Comments." Accounting Horizons 27 (4). American Accounting Assocation: 711-36.

Brochet, Francois, Alan D. Jagolinzer, and Edward J. Riedl. 2013. "Mandatory IFRS Adoption and Financial Statement Comparability." Contemporary Accounting Research 30 (4): 1373-1400.

Brown, Stephen V., and W. Robert Knechel. 2016. "Auditor-Client Compatibility and 
Audit Firm Selection." Journal of Accounting Research 54 (3): 725-75.

Brown, Stephen V., Xiaoli (Shaolee) Tian, and Jenny Wu Tucker. 2015. The Spillover Effect of SEC Comment Letters on Qualitative Corporate Disclosure: Evidence from the Risk Factor Disclosure. Unpublished Result.

Brown, Stephen V., and Jenny Wu Tucker. 2011. "Large-Sample Evidence on Firms' Yearover-Year MD\&A Modifications." Journal of Accounting Research 49 (2). Blackwell Publishing Inc: 309-46.

Cai, Ye, Yongtae Kim, Jong Chool Park, and Hal D. White. 2016. "Common Auditors in M\&A Transactions." Journal of Accounting and Economics 61 (1): 77-99.

Cassell, Cory A., Lauren M. Dreher, and Linda A. Myers. 2013. "Reviewing the SEC's Review Process: 10-K Comment Letters and the Cost of Remediation." The Accounting Review 88 (6). American Accounting Association: 1875-1908.

Chen, Tia-Yuan, and Hong-Da Wang. 2016. Auditors With or Without Styles? Evidence from Unexpected Auditor Turnovers.

Cheng, Shijun. 2008. "Board Size and the Variability of Corporate Performance." Journal of Financial Economics 87 (1): 157-76.

Christensen, Brant E., Steven M. Glover, Thomas C. Omer, and Marjorie K. Shelley. 2015. "Understanding Audit Quality: Insights from Audit Partners and Investors." Contemporary Accounting Research 33 (4): 1648-84.

De Franco, Gus, S.P. Kothari, and Rodrigo S. Verdi. 2011. "The Benefits of Financial Statement Comparability." Journal of Accounting Research 49 (4). Blackwell Publishing Inc: 895-931.

Dechow, Patricia M., Alastair Lawrence, and James Ryans. 2015. "SEC Comment Letters and Insider Sales.” The Accounting Review, Forthcoming.

DeFond, Mark, Xuesong Hu, Mingyi Hung, and Siqi Li. 2011. "The Impact of Mandatory IFRS Adoption on Foreign Mutual Fund Ownership: The Role of Comparability." Journal of Accounting and Economics 51 (3): 240-58.

DeFond, Mark, and Mingyi Hung. 2003. “An Empirical Analysis of Analysts' Cash Flow Forecasts.” Journal of Accounting and Economics 35 (1): 73-100.

Dhaliwal, Dan S., Phillip T. Lamoreaux, Lubomir P. Litov, and Jordan B. Neyland. 2016. "Shared Auditors in Mergers and Acquisitions." Journal of Accounting and Economics 61 (1): 49-76.

Dhaliwal, Dan S., Jaideep Shenoy, and Ryan Williams. 2016. Common Auditors and Relationship-Specific Investment in Supplier-Customer Relationships. 
Dowling, Carlin, and Stewart Leech. 2007. "Audit Support Systems and Decision Aids: Current Practice and Opportunities for Future Research." International Journal of Accounting Information Systems 8 (2): 92-116.

Fang, Vivian W., Mark Maffett, and Bohui Zhang. 2015. "Foreign Institutional Ownership and the Global Convergence of Financial Reporting Practices." Journal of Accounting Research 53 (3): 593-631.

Francis, Jere R., Shawn Huang, Inder K. Khurana, and Raynolde Pereira. 2009. "Does Corporate Transparency Contribute to Efficient Resource Allocation?" Journal of Accounting Research 47 (4). Blackwell Publishing Inc: 943-89.

Francis, Jere R., Matthew L. Pinnuck, and Olena Watanabe. 2013. "Auditor Style and Financial Statement Comparability." The Accounting Review 89 (2). American Accounting Association: 605-33.

Francis, Jere R., and Wei Wang. 2016. Common Auditors and Private Bank Loans. Unpublished Result.

Geiger, Marshall A., and Kannan Raghunandan. 2002. "Auditor Tenure and Audit Reporting Failures.” AUDITING: A Journal of Practice \& Theory 21 (1): 67-78.

Gietzmann, Miles B., and Helena Isidro. 2013. "Institutional Investors' Reaction to SEC Concerns about IFRS and US GAAP Reporting." Journal of Business Finance \& Accounting 40 (7-8): 796-841.

Gietzmann, Miles B., and Angela K. Pettinicchio. 2013. "External Auditor Reassessment of Client Business Risk Following the Issuance of a Comment Letter by the SEC." European Accounting Review 23 (1). Routledge: 57-85.

Glover, Steven M., James C. Hansen, and Timothy A. Seidel. 2015. The Effect of Deadline Imposed Time Pressure on Audit Quality.

Goodwin, John, and Donghui Wu. 2014. "Is the Effect of Industry Expertise on Audit Pricing an Office-Level or a Partner-Level Phenomenon?" Review of Accounting Studies 19 (4). Springer US: 1532-78.

Graham, John R., Campbell R. Harvey, and Manju Puri. 2015. "Capital Allocation and Delegation of Decision-Making Authority within Firms." Journal of Financial Economics 115 (3): 449-70.

Grant, Robert M. 1996. "Toward a Knowledge-Based Theory of the Firm." Strategic Management Journal 17 (S2). John Wiley \& Sons, Ltd.: 109-22.

Gul, Ferdinand A., Simon Yu Kit Fung, and Bikki Jaggi. 2009. "Earnings Quality: Some Evidence on the Role of Auditor Tenure and Auditors' Industry Expertise." Journal of Accounting and Economics 47 (3): 265-87. 
Gul, Ferdinand A., Donghui Wu, and Zhifeng Yang. 2013. "Do Individual Auditors Affect Audit Quality? Evidence from Archival Data." The Accounting Review 88 (6). American Accounting Association: 1993-2023.

Hayek, F.A. 1945. "The Use of Knowledge in Society." The American Economic Review 35 (4): 519-30.

Hennes, Karen M., and Kristy M. Schenck. 2014. "The Development of Reporting Norms without Explicit Guidance: An Example from Accounting for Gift Cards." Accounting Horizons 28 (3). American Accounting Assocation: 561-78.

Hribar, Paul, Todd Kravet, and Ryan Wilson. 2013. "A New Measure of Accounting Quality." Review of Accounting Studies 19 (1): 506-38.

Johnson, Van E., Inder K. Khuran, and J. Kenneth Reynolds. 2002. "Audit-Firm Tenure and the Quality of Financial Reports." Contemporary Accounting Research 19 (4). Blackwell Publishing Ltd: 637-60.

Knechel, Robert W., Ann Vanstraelen, and Mikko Zerni. 2015. "Does the Identity of Engagement Partners Matter? An Analysis of Audit Partner Reporting Decisions." Contemporary Accounting Research 32 (4): 1443-78.

Kothari, S.P., Karthik Ramanna, and Douglas J. Skinner. 2010. "Implications for GAAP from an Analysis of Positive Research in Accounting." Journal of Accounting and Economics 50 (2): 246-86.

Kwon, Soo Young, Chee Yeow Lim, and Patricia Mui-Siang Tan. 2007. "Legal Systems and Earnings Quality: The Role of Auditor Industry Specialization." AUDITING: A Journal of Practice \& Theory 26 (2): 25-55.

McMullin, Jeff L. 2016. Can I Borrow Your Footnotes? Footnote Boilerplate's Learning Externality.

Myers, James N., Linda A. Myers, and Thomas C. Omer. 2003. "Exploring the Term of the Auditor-Client Relationship and the Quality of Earnings: A Case for Mandatory Auditor Rotation?" The Accounting Review 78 (3): 779-99.

Ozkan, Neslihan, Zvi Singer, and Haifeng You. 2012. "Mandatory IFRS Adoption and the Contractual Usefulness of Accounting Information in Executive Compensation." Journal of Accounting Research 50 (4): 1077-1107.

Peterson, Kyle, Roy Schmardebeck, and T. Jeffrey Wilks. 2015. "The Earnings Quality and Information Processing Effects of Accounting Consistency." The Accounting Review 90 (6). American Accounting Association: 2483-2514.

Reichelt, Kenneth J., and Dechun Wang. 2010. "National and Office-Specific Measures of Auditor Industry Expertise and Effects on Audit Quality." Journal of Accounting Research 48 (3). Blackwell Publishing Inc: 647-86. 
Robinson, Leslie A., and Phillip C. Stocken. 2013. "Location of Decision Rights Within Multinational Firms." Journal of Accounting Research 51 (5): 1261-97.

Sah, R. K., and J. E. Stiglitz. 1991. "The Quality of Managers in Centralized Versus Decentralized Organizations." The Quarterly Journal of Economics 106 (1): 289-95.

Salton, G., A. Wong, and C. S. Yang. 1975. "A Vector Space Model for Automatic Indexing." Communications of the ACM 18 (11). ACM: 613-20.

Schwartz, Kenneth B., and Billy S. Soo. 1995. "An Analysis of Form 8-K Disclosures of Auditor Changes by Firms Approaching Bankruptcy.” Auditing 14 (1): 125-36.

. 1996. "Evidence of Regulatory Noncompliance with SEC Disclosure Rules on Auditor Changes." The Accounting Review 71 (4): 555-72.

Staff Audit Practice Alert No. 12: Matters Related to Auditing Revenue in an Audit of Financial Statements. 2014.

Wang, Clare. 2014. "Accounting Standards Harmonization and Financial Statement Comparability: Evidence from Transnational Information Transfer." Journal of Accounting Research 52 (4): 955-92.

Wang, Yanyan, Lisheng Yu, and Yuping Zhao. 2015. "The Association Between AuditPartner Quality and Engagement Quality: Evidence from Financial Report Misstatements." AUDITING: A Journal of Practice \& Theory 34 (3). American Accounting Association: 81-111.

Yip, Rita W. Y., and Danqing Young. 2012. "Does Mandatory IFRS Adoption Improve Information Comparability?" The Accounting Review 87 (5). American Accounting Association: 1767-89.

Young, Steven, and Yachang Zeng. 2015. "Accounting Comparability and the Accuracy of Peer-Based Valuation Models." The Accounting Review 90 (6). American Accounting Association: 2571-2601.

Yu, Gwen, and Aida Sijamic Wahid. 2014. "Accounting Standards and International Portfolio Holdings." The Accounting Review 89 (5). American Accounting Association: 1895-1930. 


\section{APPENDIX A \\ Variable Definitions}

This appendix provides definitions for the main regression variables. Variables appear in various letter-pairs analyses accompanied by the suffix Diff or Min. Diff means the variable is the absolute value of the difference for the variable between each comment letter in the letterpair. Min means the variable is the minimum value of the variable between each letter in the letter-pair. Continuous variables are winsorized at the 1st and 99th percentiles. Unless stated otherwise, variables are measured at time $t$ where $t$ is the fiscal year of the first annual filing referenced by a comment letter.

\begin{tabular}{|c|c|}
\hline \multicolumn{2}{|r|}{ Comment Letter Sample } \\
\hline Variable & Definition \\
\hline Keys & Number of issue keys (out of 215) noted in the comment letter. \\
\hline Types & $\begin{array}{c}\text { Number of individual issue types (out of 6) in the comment letter that have } \\
\text { at least one issue key noted. }\end{array}$ \\
\hline Rounds & $\begin{array}{c}\text { Number of communications between the client and SEC before the } \\
\text { conversation is closed. }\end{array}$ \\
\hline Days & Number of days between the first and last letter in the conversation. \\
\hline Altman Z & Altman (1968) Z Score. \\
\hline Auditor Tenure & $\begin{array}{c}\text { Number of years since the client-auditor combination first appears in Audit } \\
\text { Analytics. }\end{array}$ \\
\hline $\begin{array}{l}\text { Concurrent } \\
\text { Restatement }\end{array}$ & $\begin{array}{l}\text { Indicator variable equal to one if the client filed a restatement during the } \\
\text { fiscal year under review, and zero otherwise. }\end{array}$ \\
\hline Ext Financing & $\begin{array}{l}\text { External Financing measured as net common equity issuances minus } \\
\text { dividends plus net long term and current debt issuances. }\end{array}$ \\
\hline Filings & Number of SEC filings referenced in the comment letter. \\
\hline Firm Age & Number of years since the client first appears in Compustat. \\
\hline High Volatility & $\begin{array}{c}\text { Indicator variable equal to one if the client's standard deviation of quarterly } \\
\text { common equity prices for the prior twelve quarters is in the top quartile of } \\
\text { the sample year, and zero otherwise. }\end{array}$ \\
\hline$I C M W$ & $\begin{array}{c}\text { Indicator variable equal to one if the auditor noted a material weakness in } \\
\text { internal controls, and zero otherwise. }\end{array}$ \\
\hline Litigation Risk & $\begin{array}{l}\text { Indicator variable equal to one if the firm is in any of the following 4-digit } \\
\text { SIC codes: } 2833-2836,3570-3577,3600-3674,5200-5961,7370-7374 \text {, and } \\
\text { zero otherwise. }\end{array}$ \\
\hline$L n M V$ & $\begin{array}{l}\text { Natural logarithm of market capitalization measured as the shares of } \\
\text { common equity outstanding times the fiscal year's closing price per share. }\end{array}$ \\
\hline Loss & Indicator variable equal to one if the firm has negative pretax income. \\
\hline$M N A$ & $\begin{array}{c}\text { Indicator variable equal to one if the firm has non-zero acquisition costs, } \\
\text { and zero otherwise. }\end{array}$ \\
\hline Restructure & $\begin{array}{l}\text { Indicator variable equal to one if the firm has nonzero restructuring costs, } \\
\text { and zero otherwise. }\end{array}$ \\
\hline$R O A$ & Return on Assets measured as pretax income scaled by total assets. \\
\hline Sales Growth & Percentage change in total sales. \\
\hline Segments & Number of business segments. \\
\hline
\end{tabular}




\section{APPENDIX A CONTINUED \\ Variable Definitions}

This appendix provides definitions for the main regression variables. Variables appear in various letter-pairs analyses accompanied by the suffix Diff or Min. Diff means the variable is the absolute value of the difference for the variable between each comment letter in the letterpair. Min means the variable is the minimum value of the variable between each letter in the letter-pair. Continuous variables are winsorized at the 1st and 99th percentiles. Unless stated otherwise, variables are measured at time $t$ where $t$ is the fiscal year of the first annual filing referenced by a comment letter.

\begin{tabular}{|c|c|}
\hline \multicolumn{2}{|r|}{ Letter-Pairs Sample } \\
\hline Variable & Definition \\
\hline Same Auditor & $\begin{array}{l}\text { Indicator variable equal to one if both clients in a letter-pair } \\
\text { have the same audit firm, and zero otherwise. }\end{array}$ \\
\hline Similar Keys & $\begin{array}{l}\text { Number of issue keys (out of } 215 \text { ) that appear in both letters } \\
\text { in a letter-pair, scaled by the total number of keys noted in } \\
\text { both letters. Values are multiplied by } 100 \text { for ease of } \\
\text { interpretation. }\end{array}$ \\
\hline Similar Types & $\begin{array}{l}\text { Number of issue types (out of nine) where both letters in a } \\
\text { letter-pair have at least one issue key noted for that type, } \\
\text { scaled by the number of types in both letters that have at least } \\
\text { one key noted. Values are multiplied by } 100 \text { for ease of } \\
\text { interpretation. }\end{array}$ \\
\hline Similar Text & $\begin{array}{c}\text { The similarity of the textual content of the two comment } \\
\text { letters in a pair using the Salton, Wong, \& Yang (1975) } \\
\text { Vector Space Model using word stemming and removing } \\
\text { stop words and proper nouns. Values are multiplied by } 100 \\
\text { for ease of interpretation. }\end{array}$ \\
\hline \multicolumn{2}{|r|}{ Auditor Style and the Effect of Tenure } \\
\hline Variable & Definition \\
\hline Long Tenure & $\begin{array}{l}\text { Indicator variable equal to one if a both letters in the letter- } \\
\text { pair have been with their auditor for five or more years, and } \\
\text { zero otherwise. }\end{array}$ \\
\hline \multicolumn{2}{|c|}{ Auditor Changes and Assuming Disclosure Deficiencies } \\
\hline Variable & Definition \\
\hline Switch & $\begin{array}{c}\text { Indicator variable equal to one if the two clients in the } \\
\text { modified letter-pair have the same auditor, and zero } \\
\text { otherwise. }\end{array}$ \\
\hline \multicolumn{2}{|r|}{ Self-Fulfilling Prophecy } \\
\hline Variable & Definition \\
\hline Prior Issue Auditor & $\begin{array}{l}\text { Indicator variable equal to one if, in the prior } 365 \text { days, } \\
\text { another comment letter for a client with the same industry } \\
\text { and audit firm had an issue noted for a particular type, and } \\
\text { zero otherwise. }\end{array}$ \\
\hline \multicolumn{2}{|c|}{ Auditor Style and Overall Disclosure Quality } \\
\hline Variable & Definition \\
\hline Letter & $\begin{array}{c}\text { variable equal to one if the client received a letter referencing } \\
\text { year } t \text {, and zero otherwise. }\end{array}$ \\
\hline
\end{tabular}




\section{APPENDIX B \\ Comment Letter Pairing Process}

This appendix describes the pairing process that creates the comment-letter-pair observations for the main analysis.

The comment letter sample is first subdivided into groups based on a) the 2 digit SIC code of the client under review and b) the fiscal year of the first annual filing mentioned in the comment letter. Within each industry-year group all comment letters are matched to all other comment letters creating a panel of letter-pair observations. Note the sample is restricted so that a client may only have one comment letter for any one annual filing/fiscal year, so clients are never paired with themselves. This process produces a number of letterpair observations for each industry-year group equal to $\sum_{i=1}^{n} i-1$. The diagram below illustrates the process for an industry-year group that has four comment letters $(n=4)$ and six letter-pair observations.

\begin{tabular}{|c|}
\hline 2 Digit SIC Code $=25$ \\
Fiscal Year $=2008$ \\
\hline Letter 1 \\
Letter 2 \\
Letter 3 \\
Letter 4 \\
\hline
\end{tabular}

\begin{tabular}{|c|c|cc|cc|cc|}
\hline \multicolumn{7}{|c|}{ Generate Comment-Letter-Pair Observations } \\
\hline \multicolumn{2}{|c|}{ Letter 1 } & \multicolumn{2}{|c|}{ Letter 2 } & \multicolumn{2}{c|}{ Letter 3 } & \multicolumn{2}{c|}{ Letter 4 } \\
\hline Letter 1 & Letter 1 & Letter 1 & Letter 1 & Letter 1 & Letter 1 & Letter 1 & Letter 1 \\
Letter 2 & Letter 2 & Letter 2 & Letter 2 & Letter 2 & Letter 2 & Letter 2 & Letter 2 \\
Letter 3 & Letter 3 & Letter 3 & Letter 3 & Letter 3 & Letter 3 & Letter 3 & Letter 3 \\
Letter 4 & Letter 4 & Letter 4 & Letter 4 & Letter 4 & Letter 4 & Letter 4 & Letter 4 \\
\hline
\end{tabular}

Resulting Comment-Letter-Pair Observations
Letter $1+$ Letter 2
Letter $1+$ Letter 3
Letter $1+$ Letter 4
Letter 2 + Letter 3
Letter $2+$ Letter 4
Letter 3 + Letter 4 


\section{APPENDIX C \\ Comment Letter Pairing Process for the Auditor Changes Analysis}

This appendix describes the pairing process that creates the modified letter-pair sample used for the auditor changes analysis. Clients are grouped into Switcher and Non-Switcher subsamples based on whether or not they received comment letters for fiscal years audited by different audit firms. The exact requirements for each group are:

\section{Switchers}

- Must have at least two comment letters in the comment letter sample.

- Must have exactly two audit firms for all comment letters.

\section{Non-Switchers}

- Must have exactly one audit firm for all comment letters.

Clients that do not meet the requirements for either group (e.g., they received comment letters for three audit firms) are deleted. Switcher letters are paired to Non-Switcher letters if the Non-Switcher letter has a) the same industry and fiscal year and b) the Switcher's post-change auditor. The Switch indicator variable then equals one for letter-pairs where the Switcher and Non-Switcher have the same audit firm. In other words, Switchers are paired with the clients of the auditor they change to, and the Switch indicator equals one for letters they receive after the change. The diagram below illustrates the process for one Switcher that has comment letters in two different years.

\begin{tabular}{|c|c|}
\hline $\begin{array}{l}2 \text { Digit SIC Code }=25 \\
\text { Fiscal Year }=2008\end{array}$ & $\begin{array}{c}2 \text { Digit SIC Code }=25 \\
\text { Fiscal Year }=2010\end{array}$ \\
\hline $\begin{array}{cc}\text { Switcher } & \text { Non-Switchers } \\
\text { Letter 1-Client A-Firm X } & \text { Letter 2-Client B-Firm X } \\
& \text { Letter 3-Client C-Firm X } \\
\text { Letter 4-Client D-Firm Y }\end{array}$ & $\begin{array}{cc}\text { Switcher } & \text { Non-Switchers } \\
\text { Letter 5-Client A-Firm Y } & \text { Letter 6-Client B-Firm X } \\
& \text { Letter 7-Client D-Firm Y } \\
& \text { Letter 8-Client F-Firm Y }\end{array}$ \\
\hline
\end{tabular}

\begin{tabular}{|c|c|}
\hline \multicolumn{2}{|c|}{ Resulting Comment-Letter-Pair Observations } \\
\hline Comment-Letter-Pair & Switch \\
\hline Letter 1-Client A-Firm X + Letter 4-Client D-Firm Y & 0 \\
Letter 5-Client A-Firm Y + Letter 7-Client D-Firm Y & 1 \\
Letter 5-Client A-Firm Y + Letter 8-Client F-Firm Y & 1 \\
\hline
\end{tabular}




\section{TABLE 1}

Sample Construction

This table describes the steps required to construct/replicate the main comment letter sample.

\begin{tabular}{|c|c|c|}
\hline Step & Desc & Obs \\
\hline 1 & $\begin{array}{l}\text { Retrieve the Audit Analytics Commlett file (June } 2016 \text { snapshot) and } \\
\text { remove observations with missing company identifier (company_fkey) } \\
\text { and conversation identifier (cl_con_id). }\end{array}$ & 273,333 \\
\hline 2 & $\begin{array}{l}\text { Remove entire conversations where the first correspondence is not } \\
\text { initiated by the SEC (form_fkey= "UPLOAD"). }\end{array}$ & 218,582 \\
\hline 3 & $\begin{array}{l}\text { Remove entire conversations without a No Further Comment letter } \\
\text { (iss_wholet_keys contains "|266|" in the final letter of the conversation). }\end{array}$ & 133,589 \\
\hline 4 & $\begin{array}{l}\text { Remove entire conversations where there is only one letter from the SEC } \\
\text { (form_fkey = "UPLOAD").. }\end{array}$ & 132,464 \\
\hline 5 & Remove entire conversations with less than three letters. & 130,558 \\
\hline 6 & $\begin{array}{l}\text { Remove entire conversations where the Audit Analytics Commlettconv } \\
\text { file first letter date (first_letter_date) and/or last letter date } \\
\text { (last_letter_date) do not match the first/last letter dates on the Commlett } \\
\text { file (event_date). }\end{array}$ & 130,214 \\
\hline 7 & $\begin{array}{l}\text { Remove entire conversations where the first correspondence doesn't } \\
\text { reference a company annual filling (web_grp_fil_ref contains " } 10-\mathrm{K} \text { ", } \\
\text { "10K", "20-F" or " } 20 \mathrm{~F} ") \text {. }\end{array}$ & 112,915 \\
\hline 8 & $\begin{array}{l}\text { Remove entire conversations where the first letter does not reference one } \\
\text { of the six major issue types (iss_accrldisc_keys, iss_dcic_keys } \\
\text { iss_man_disc_keys, iss_regstatem_keys, iss_riskfact_keys or } \\
\text { iss_othrdisc_keys not equal missing). }\end{array}$ & 111,517 \\
\hline 9 & $\begin{array}{l}\text { Compress the file down to the first correspondence for each } \\
\text { conversation. }\end{array}$ & 22,567 \\
\hline 10 & $\begin{array}{l}\text { Merge the Commlett file and the Audit Analytics } \\
\text { AuditOpin/AuditSox } 404 \text { files. Comment letters are merged to the fiscal } \\
\text { year associated with the first annual filling noted in the comment letter. }\end{array}$ & 14,429 \\
\hline 11 & Merge the Commlett file with the Compustat Funda file. & 13,771 \\
\hline 12 & Remove observations with fiscal years before 2004 or after 2013. & 12,932 \\
\hline 13 & Remove observations with missing control data. & 12,666 \\
\hline 14 & Remove clients with a non-Big 4 auditor. & 10,840 \\
\hline 15 & Remove clients with less than $\$ 10 \mathrm{M}$ in assets. & 10,830 \\
\hline 16 & Remove observations where the client changed auditors during the year. & 10,536 \\
\hline
\end{tabular}




\section{TABLE 2 \\ PANEL A \\ Descriptive Statistics \\ Comment Letter Sample}

This table presents descriptive statistics for the comment letter sample. The sample selection process is described in Table 1. All variables are defined in Appendix A.

\begin{tabular}{lcccccccc}
\hline \multicolumn{1}{c}{ Variable } & $\mathbf{N}$ & Mean & P10 & P25 & P50 & P75 & P90 & SD \\
\hline Keys & 10,536 & 5.957 & 2 & 3 & 5 & 8 & 12 & 3.980 \\
Types & 10,536 & 2.540 & 1 & 2 & 3 & 3 & 4 & 0.975 \\
Altman Z & 10,536 & 3.323 & 0.215 & 0.946 & 2.364 & 4.304 & 7.253 & 4.272 \\
Auditor Tenure & 10,536 & 7.771 & 3 & 5 & 8 & 10 & 12 & 3.376 \\
Concurrent Restatement & 10,536 & 0.070 & 0 & 0 & 0 & 0 & 0 & 0.254 \\
Ext Financing & 10,536 & -0.005 & -0.056 & 0.000 & 0.000 & 0.000 & 0.020 & 0.065 \\
Filings & 10,536 & 1.632 & 1 & 1 & 1 & 2 & 3 & 0.867 \\
Firm Age & 10,536 & 23.519 & 7 & 11 & 18 & 32 & 53 & 16.759 \\
High Volatility & 10,536 & 0.268 & 0 & 0 & 0 & 1 & 1 & 0.443 \\
ICMW & 10,536 & 0.039 & 0 & 0 & 0 & 0 & 0 & 0.193 \\
Litigation Risk & 10,536 & 0.211 & 0 & 0 & 0 & 0 & 1 & 0.408 \\
LnMV & 10,536 & 7.596 & 5.338 & 6.342 & 7.545 & 8.760 & 9.971 & 1.760 \\
Loss & 10,536 & 0.210 & 0 & 0 & 0 & 0 & 1 & 0.408 \\
MNA & 10,536 & 0.452 & 0 & 0 & 0 & 1 & 1 & 0.498 \\
Restructure & 10,536 & 0.332 & 0 & 0 & 0 & 1 & 1 & 0.471 \\
ROA & 10,536 & 0.040 & -0.070 & 0.007 & 0.048 & 0.103 & 0.171 & 0.140 \\
Sales Growth & 10,536 & 0.121 & -0.151 & -0.023 & 0.070 & 0.192 & 0.391 & 0.343 \\
Segments & 10,536 & 1.783 & 1 & 1 & 1 & 2 & 4 & 1.506 \\
\hline
\end{tabular}




\section{TABLE 2 \\ PANEL B \\ Descriptive Statistics \\ Letter-Pairs Sample}

This table presents descriptive statistics for the letter-pairs sample. All variables are defined in Appendix A. The comment letter pairing process is described in Appendix B.

\begin{tabular}{|c|c|c|c|c|c|c|c|c|}
\hline Variable & $\mathbf{N}$ & Mean & P10 & $\mathbf{P 2 5}$ & P50 & P75 & P90 & SD \\
\hline Same Auditor & 247,782 & 0.270 & 0 & 0 & 0 & 1 & 1 & 0.444 \\
\hline Similar Keys & 247,782 & 11.039 & 0.000 & 0.000 & 10.526 & 16.667 & 25.000 & 9.678 \\
\hline Similar Types & 247,782 & 9.329 & 4.167 & 5.714 & 8.333 & 11.111 & 16.667 & 6.152 \\
\hline Similar Text & 244,409 & 57.894 & 49.216 & 53.142 & 57.710 & 62.273 & 66.667 & 7.396 \\
\hline Altman Z Diff & 247,782 & 3.701 & 0.129 & 0.532 & 1.759 & 4.639 & 9.639 & 5.099 \\
\hline Altman Z Min & 247,782 & 1.521 & -0.354 & 0.274 & 1.297 & 2.764 & 4.271 & 2.641 \\
\hline Auditor Tenure Diff & 247,782 & 3.218 & 0 & 1 & 2 & 5 & 7 & 2.797 \\
\hline Auditor Tenure Min & 247,782 & 6.176 & 2 & 4 & 6 & 8 & 10 & 3.085 \\
\hline Concurrent Restatement Diff & 247,782 & 0.112 & 0 & 0 & 0 & 0 & 1 & 0.315 \\
\hline Concurrent Restatement Min & 247,782 & 0.004 & 0 & 0 & 0 & 0 & 0 & 0.066 \\
\hline Ext Financing Diff & 247,782 & 0.051 & 0.000 & 0.000 & 0.015 & 0.069 & 0.158 & 0.079 \\
\hline Ext Financing Min & 247,782 & -0.030 & -0.107 & -0.037 & 0.000 & 0.000 & 0.000 & 0.061 \\
\hline Filings Diff & 247,782 & 0.773 & 0 & 0 & 1 & 1 & 2 & 0.866 \\
\hline Filings Min & 247,782 & 1.250 & 1 & 1 & 1 & 1 & 2 & 0.509 \\
\hline Firm Age Diff & 247,782 & 15.289 & 1 & 4 & 10 & 23 & 40 & 14.334 \\
\hline Firm Age Min & 247,782 & 14.358 & 5 & 8 & 12 & 17 & 25 & 10.717 \\
\hline High Volatility Diff & 247,782 & 0.351 & 0 & 0 & 0 & 1 & 1 & 0.477 \\
\hline High Volatility Min & 247,782 & 0.065 & 0 & 0 & 0 & 0 & 0 & 0.246 \\
\hline ICMW Diff & 247,782 & 0.066 & 0 & 0 & 0 & 0 & 0 & 0.248 \\
\hline ICMW Min & 247,782 & 0.002 & 0 & 0 & 0 & 0 & 0 & 0.045 \\
\hline Litigation Risk Diff & 247,782 & 0.201 & 0 & 0 & 0 & 0 & 1 & 0.401 \\
\hline Litigation Risk Min & 247,782 & 0.179 & 0 & 0 & 0 & 0 & 1 & 0.383 \\
\hline LnMV Diff & 247,782 & 1.898 & 0.289 & 0.738 & 1.582 & 2.742 & 3.963 & 1.458 \\
\hline LnMV Min & 247,782 & 6.608 & 4.791 & 5.562 & 6.610 & 7.577 & 8.414 & 1.436 \\
\hline Loss Diff & 247,782 & 0.335 & 0 & 0 & 0 & 1 & 1 & 0.472 \\
\hline Loss Min & 247,782 & 0.066 & 0 & 0 & 0 & 0 & 0 & 0.248 \\
\hline MNA Diff & 247,782 & 0.445 & 0 & 0 & 0 & 1 & 1 & 0.497 \\
\hline MNA Min & 247,782 & 0.237 & 0 & 0 & 0 & 0 & 1 & 0.425 \\
\hline Restructure Diff & 247,782 & 0.386 & 0 & 0 & 0 & 1 & 1 & 0.487 \\
\hline Restructure Min & 247,782 & 0.152 & 0 & 0 & 0 & 0 & 1 & 0.359 \\
\hline ROA Diff & 247,782 & 0.131 & 0.008 & 0.025 & 0.071 & 0.167 & 0.338 & 0.162 \\
\hline ROA Min & 247,782 & -0.037 & -0.264 & -0.046 & 0.011 & 0.049 & 0.092 & 0.167 \\
\hline Sales Growth Diff & 247,782 & 0.300 & 0.028 & 0.073 & 0.170 & 0.351 & 0.664 & 0.406 \\
\hline Sales Growth Min & 247,782 & -0.018 & -0.268 & -0.102 & 0.007 & 0.085 & 0.178 & 0.207 \\
\hline Segments Diff & 247,782 & 0.937 & 0 & 0 & 0 & 2 & 3 & 1.515 \\
\hline Segments Min & 247,782 & 1.278 & 1 & 1 & 1 & 1 & 2 & 0.824 \\
\hline
\end{tabular}




\section{TABLE 2 \\ PANEL C \\ Descriptive Statistics \\ Letter-Pairs Sample}

This table presents descriptive statistics and tests of differences in means for the letter-pairs sample split on the value of Same Auditor. All variables are defined in Appendix A. The comment letter pairing process is described in Appendix B.

\begin{tabular}{|c|c|c|c|c|c|c|c|c|c|}
\hline \multirow[b]{2}{*}{ Variable } & \multicolumn{3}{|c|}{ Same Auditor $=0$} & \multicolumn{3}{|c|}{ Same Auditor $=1$} & \multicolumn{3}{|c|}{ Test of Difference in Means } \\
\hline & $\mathbf{N}$ & Mean & SD & $\mathbf{N}$ & Mean & SD & Difference & T Stat & P Val \\
\hline Similar Keys & 180,871 & 10.976 & 9.644 & 66,911 & 11.210 & 9.769 & 0.234 & 5.310 & 0.000 \\
\hline Similar Types & 180,871 & 9.305 & 6.136 & 66,911 & 9.393 & 6.195 & 0.088 & 3.133 & 0.003 \\
\hline Similar Text & 178,294 & 57.833 & 7.525 & 66,115 & 58.061 & 7.035 & 0.228 & 6.977 & 0.000 \\
\hline Altman Z Diff & 180,871 & 3.706 & 5.086 & 66,911 & 3.688 & 5.137 & -0.017 & -0.747 & 0.302 \\
\hline Altman Z Min & 180,871 & 1.525 & 2.637 & 66,911 & 1.511 & 2.651 & -0.013 & -1.109 & 0.216 \\
\hline Auditor Tenure Diff & 180,871 & 3.237 & 2.798 & 66,911 & 3.166 & 2.792 & -0.070 & -5.569 & 0.000 \\
\hline Auditor Tenure Min & 180,871 & 6.159 & 3.080 & 66,911 & 6.222 & 3.097 & 0.063 & 4.520 & 0.000 \\
\hline Concurrent Restatement Diff & 180,871 & 0.113 & 0.316 & 66,911 & 0.109 & 0.312 & -0.003 & -2.464 & 0.019 \\
\hline Concurrent Restatement Min & 180,871 & 0.004 & 0.066 & 66,911 & 0.005 & 0.068 & 0.000 & 0.854 & 0.277 \\
\hline Ext Financing Diff & 180,871 & 0.051 & 0.079 & 66,911 & 0.051 & 0.080 & 0.000 & 0.444 & 0.362 \\
\hline Ext Financing Min & 180,871 & -0.031 & 0.062 & 66,911 & -0.029 & 0.061 & 0.001 & 4.112 & 0.000 \\
\hline Filings Diff & 180,871 & 0.773 & 0.868 & 66,911 & 0.773 & 0.861 & 0.001 & 0.214 & 0.390 \\
\hline Filings Min & 180,871 & 1.248 & 0.508 & 66,911 & 1.255 & 0.512 & 0.006 & 2.734 & 0.010 \\
\hline Firm Age Diff & 180,871 & 15.462 & 14.396 & 66,911 & 14.822 & 14.154 & -0.639 & -9.937 & 0.000 \\
\hline Firm Age Min & 180,871 & 14.243 & 10.469 & 66,911 & 14.671 & 11.353 & 0.429 & 8.519 & 0.000 \\
\hline High Volatility Diff & 180,871 & 0.353 & 0.478 & 66,911 & 0.346 & 0.476 & -0.007 & -3.364 & 0.001 \\
\hline High Volatility Min & 180,871 & 0.065 & 0.246 & 66,911 & 0.064 & 0.245 & -0.001 & -0.477 & 0.356 \\
\hline ICMW Diff & 180,871 & 0.067 & 0.250 & 66,911 & 0.063 & 0.242 & -0.004 & -3.625 & 0.001 \\
\hline ICMW Min & 180,871 & 0.002 & 0.045 & 66,911 & 0.002 & 0.045 & 0.000 & -0.068 & 0.398 \\
\hline Litigation Risk Diff & 180,871 & 0.204 & 0.403 & 66,911 & 0.193 & 0.395 & -0.011 & -5.894 & 0.000 \\
\hline Litigation Risk Min & 180,871 & 0.176 & 0.381 & 66,911 & 0.184 & 0.388 & 0.008 & 4.609 & 0.000 \\
\hline LnMV Diff & 180,871 & 1.907 & 1.462 & 66,911 & 1.873 & 1.449 & -0.034 & -5.209 & 0.000 \\
\hline LnMV Min & 180,871 & 6.612 & 1.438 & 66,911 & 6.597 & 1.431 & -0.015 & -2.300 & 0.028 \\
\hline Loss Diff & 180,871 & 0.335 & 0.472 & 66,911 & 0.333 & 0.471 & -0.002 & -1.060 & 0.227 \\
\hline Loss Min & 180,871 & 0.065 & 0.246 & 66,911 & 0.069 & 0.254 & 0.005 & 3.995 & 0.000 \\
\hline MNA Diff & 180,871 & 0.448 & 0.497 & 66,911 & 0.437 & 0.496 & -0.010 & -4.555 & 0.000 \\
\hline MNA Min & 180,871 & 0.240 & 0.427 & 66,911 & 0.228 & 0.420 & -0.012 & -6.147 & 0.000 \\
\hline Restructure Diff & 180,871 & 0.390 & 0.488 & 66,911 & 0.376 & 0.484 & -0.015 & -6.765 & 0.000 \\
\hline Restructure Min & 180,871 & 0.152 & 0.360 & 66,911 & 0.151 & 0.358 & -0.002 & -1.066 & 0.226 \\
\hline ROA Diff & 180,871 & 0.131 & 0.162 & 66,911 & 0.131 & 0.164 & 0.000 & -0.192 & 0.392 \\
\hline ROA Min & 180,871 & -0.036 & 0.167 & 66,911 & -0.039 & 0.169 & -0.003 & -4.491 & 0.000 \\
\hline Sales Growth Diff & 180,871 & 0.299 & 0.404 & 66,911 & 0.303 & 0.412 & 0.004 & 2.098 & 0.044 \\
\hline Sales Growth Min & 180,871 & -0.019 & 0.205 & 66,911 & -0.015 & 0.212 & 0.003 & 3.585 & 0.001 \\
\hline Segments Diff & 180,871 & 0.949 & 1.529 & 66,911 & 0.903 & 1.477 & -0.046 & -6.803 & 0.000 \\
\hline Segments Min & 180,871 & 1.276 & 0.820 & 66,911 & 1.285 & 0.838 & 0.009 & 2.343 & 0.026 \\
\hline
\end{tabular}




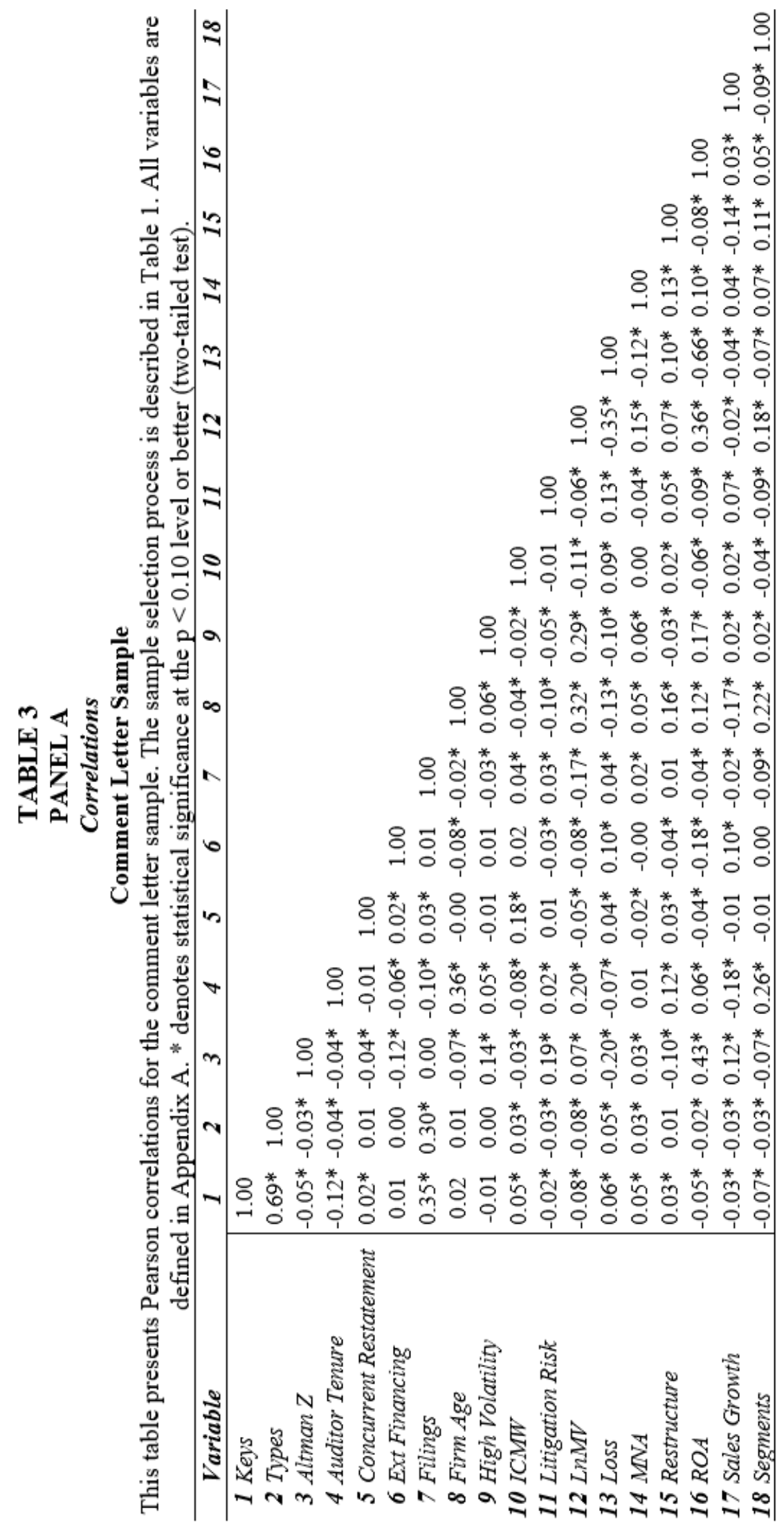




\section{TABLE 3 \\ PANEL B \\ Correlations \\ Letter-Pairs Sample}

This table presents Pearson correlations between Same Auditor and the three

measures of comment letter similarity using the letter-pairs sample. All variables are defined in Appendix A. The comment letter pairing process is described in Appendix B. * denotes statistical significance at the $p<0.10$ level or better (two-tailed test).

\begin{tabular}{l|cccc}
\hline \multicolumn{1}{c}{ Variable } & $\mathbf{1}$ & $\mathbf{2}$ & $\mathbf{3}$ & $\mathbf{4}$ \\
\hline $\mathbf{1}$ Same Auditor & 1.00 & & & \\
2 Similar Keys & $0.01 *$ & 1.00 & & \\
3 Similar Types & $0.01^{*}$ & $0.27^{*}$ & 1.00 & \\
4 Similar Text & $0.01^{*}$ & $0.25^{*}$ & $0.26^{*}$ & 1.00 \\
\hline
\end{tabular}




\section{TABLE 4 \\ Auditor Style and SEC Comment Letter Similarity \\ Letter-Pairs Sample}

This table presents tests of H1 using equation (1), the letter-pairs sample and the three measures of comment letter similarity. All variables are defined in Appendix A. The comment letter pairing process is described in Appendix B. T-statistics are in parentheses. $* * *, * * *$ denote statistical significance at the $\mathrm{p}<0.10, \mathrm{p}<0.05$ and $\mathrm{p}<0.01$ levels (two-tailed test), respectively. A

positive coefficient on Same Auditor is consistent with auditor style manifesting in common disclosure deficiencies as measured by more similar comment letters.

\begin{tabular}{|c|c|c|c|}
\hline Dependent Variable = & $\begin{array}{c}(1) \\
\text { Similar Keys }\end{array}$ & $\begin{array}{c}(2) \\
\text { Similar Types }\end{array}$ & $\begin{array}{c}\text { (3) } \\
\text { Similar Text }\end{array}$ \\
\hline \multirow[t]{2}{*}{ Same Auditor } & 0.157 & 0.047 & 0.169 \\
\hline & $(3.61)^{* * *}$ & $(1.71)^{*}$ & $(5.67) * * *$ \\
\hline \multirow[t]{2}{*}{ Altman Z Diff } & -0.007 & -0.004 & 0.008 \\
\hline & $(-1.53)$ & $(-1.23)$ & $(2.23)^{* *}$ \\
\hline \multirow[t]{2}{*}{ Altman Z Min } & 0.088 & 0.024 & 0.086 \\
\hline & $(9.36) * * *$ & $(3.77) * * *$ & $(12.70) * * *$ \\
\hline \multirow[t]{2}{*}{ Auditor Tenure Diff } & 0.031 & 0.018 & 0.051 \\
\hline & $(2.87)^{* * *}$ & $(2.62) * * *$ & $(6.30) * * *$ \\
\hline \multirow[t]{2}{*}{ Auditor Tenure Min } & 0.016 & 0.029 & 0.063 \\
\hline & $(1.56)$ & $(4.28)^{* * *}$ & $(8.35)^{* * *}$ \\
\hline \multirow[t]{2}{*}{ Concurrent Restatement Diff } & -0.255 & 0.055 & -0.150 \\
\hline & $(-4.23)^{* * *}$ & $(1.34)$ & $(-3.60) * * *$ \\
\hline \multirow[t]{2}{*}{ Concurrent Restatement Min } & 0.180 & -0.047 & -0.330 \\
\hline & $(0.65)$ & $(-0.27)$ & $(-1.86)^{*}$ \\
\hline \multirow[t]{2}{*}{ Ext Financing Diff } & -0.048 & -0.277 & -0.978 \\
\hline & $(-0.16)$ & $(-1.39)$ & $(-5.00) * * *$ \\
\hline \multirow[t]{2}{*}{ Ext Financing Min } & -0.822 & -0.615 & -0.631 \\
\hline & $(-2.07)^{* *}$ & $(-2.43) * *$ & $(-1.73)^{*}$ \\
\hline \multirow[t]{2}{*}{ Filings Diff } & 0.134 & -0.558 & -1.020 \\
\hline & $(6.24)^{* * *}$ & $(-41.04)^{* * *}$ & $(-62.81)^{* * *}$ \\
\hline \multirow[t]{2}{*}{ Filings Min } & 2.928 & -0.396 & -0.253 \\
\hline & $(80.82) * * *$ & $(-19.80)^{* * *}$ & $(-10.16)^{* * *}$ \\
\hline \multirow[t]{2}{*}{ Firm Age Diff } & -0.004 & -0.000 & -0.008 \\
\hline & $(-2.59)^{* * *}$ & $(-0.01)$ & $(-7.84) * * *$ \\
\hline \multirow[t]{2}{*}{ Firm Age Min } & 0.025 & 0.009 & 0.024 \\
\hline & $(10.63)^{* * *}$ & $(5.99) * * *$ & $(14.24)^{* * *}$ \\
\hline \multirow[t]{2}{*}{ High Volatility Diff } & 0.253 & 0.018 & -0.206 \\
\hline & $(6.00)^{* * *}$ & $(0.66)$ & $(-6.77)^{* * *}$ \\
\hline \multirow[t]{2}{*}{ High Volatility Min } & 0.563 & 0.190 & -0.309 \\
\hline & $(6.53)^{* * *}$ & $(3.38)^{* * *}$ & $(-5.38)^{* * *}$ \\
\hline \multirow[t]{2}{*}{ ICMW Diff } & -1.446 & -1.233 & -0.508 \\
\hline & $(-19.76) * * *$ & $(-25.07) * * *$ & $(-10.40)^{* * *}$ \\
\hline \multirow[t]{2}{*}{ ICMW Min } & -1.573 & -1.926 & -0.739 \\
\hline & $(-4.15)^{* * *}$ & $(-8.53)^{* * *}$ & $(-3.09) * * *$ \\
\hline \multirow[t]{2}{*}{ Litigation Risk Diff } & -0.846 & -0.266 & -0.601 \\
\hline & $(-13.03)^{* * *}$ & $(-6.66)^{* * *}$ & $(-13.51)^{* * *}$ \\
\hline Litigation Risk Min & 0.188 & 0.622 & 2.391 \\
\hline
\end{tabular}




\begin{tabular}{|c|c|c|c|}
\hline & $(2.16)^{* *}$ & $(11.44)^{* * *}$ & $(38.34) * * *$ \\
\hline \multirow[t]{2}{*}{ LnMV Diff } & -0.460 & -0.153 & -0.334 \\
\hline & $(-28.92)^{* * *}$ & $(-15.07) * * *$ & $(-28.63) * * *$ \\
\hline \multirow[t]{2}{*}{ LnMV Min } & -0.296 & -0.135 & -0.162 \\
\hline & $(-14.39) * * *$ & $(-10.32)^{* * *}$ & $(-9.76)^{* * *}$ \\
\hline \multirow[t]{2}{*}{ Loss Diff } & 0.370 & -0.314 & -0.419 \\
\hline & $(7.11)^{* * *}$ & $(-9.70) * * *$ & $(-11.25)^{* * *}$ \\
\hline \multirow[t]{2}{*}{ Loss Min } & 0.474 & -0.303 & -0.616 \\
\hline & $(4.57)^{* * *}$ & $(-4.81) * * *$ & $(-8.82)^{* * *}$ \\
\hline \multirow[t]{2}{*}{ MNA Diff } & -0.228 & -0.253 & -0.299 \\
\hline & $(-4.80)^{* * *}$ & $(-8.14)^{* * *}$ & $(-8.59)^{* * *}$ \\
\hline \multirow[t]{2}{*}{ MNA Min } & 0.019 & -0.377 & -0.269 \\
\hline & $(0.32)$ & $(-10.18)^{* * *}$ & $(-6.60) * * *$ \\
\hline \multirow[t]{2}{*}{ Restructure Diff } & -0.072 & -0.041 & -0.369 \\
\hline & $(-1.58)$ & $(-1.39)$ & $(-10.70)^{* * *}$ \\
\hline \multirow[t]{2}{*}{ Restructure Min } & 0.469 & 0.184 & 0.023 \\
\hline & $(7.09)^{* * *}$ & $(4.33) * * *$ & $(0.49)$ \\
\hline \multirow[t]{2}{*}{ ROA Diff } & -3.865 & -0.474 & -2.182 \\
\hline & $(-14.17)^{* * *}$ & $(-2.59) * * *$ & $(-10.96)^{* * *}$ \\
\hline \multirow[t]{2}{*}{ ROA Min } & -3.541 & -1.220 & -2.344 \\
\hline & $(-11.75)^{* * *}$ & $(-6.07)^{* * *}$ & $(-10.96)^{* * *}$ \\
\hline \multirow[t]{2}{*}{ Sales Growth Diff } & -0.335 & 0.024 & -0.445 \\
\hline & $(-6.66)^{* * *}$ & $(0.73)$ & $(-13.69) * * *$ \\
\hline \multirow[t]{2}{*}{ Sales Growth Min } & 0.652 & 0.809 & 0.749 \\
\hline & $(6.38)^{* * *}$ & $(11.35)^{* * *}$ & $(10.85)^{* * *}$ \\
\hline \multirow[t]{2}{*}{ Segments Diff } & -0.084 & 0.039 & -0.004 \\
\hline & $(-5.18)^{* * *}$ & $(3.68) * * *$ & $(-0.31)$ \\
\hline \multirow[t]{2}{*}{ Segments Min } & -0.102 & 0.055 & 0.050 \\
\hline & $(-3.68)^{* * *}$ & $(3.03)^{* * *}$ & $(2.58)^{* * *}$ \\
\hline \multirow[t]{2}{*}{ Constant } & 5.196 & 10.992 & 61.718 \\
\hline & $(3.17)^{* * *}$ & $(15.30)^{* * *}$ & $(85.59) * * *$ \\
\hline \multirow{3}{*}{$\begin{array}{l}\text { Industry and Year Fixed Effects } \\
\text { Robust Standard Errors } \\
\text { Clustered by Unique Gvkey Pair }\end{array}$} & $\mathrm{Y}$ & $\mathrm{Y}$ & $\mathrm{Y}$ \\
\hline & $\mathrm{Y}$ & $Y$ & \\
\hline & $Y$ & $Y$ & $Y$ \\
\hline Observations & 247,782 & 247,782 & 244,409 \\
\hline $\mathrm{R}^{2}$ & 0.081 & 0.037 & 0.236 \\
\hline Adjusted $\mathrm{R}^{2}$ & 0.081 & 0.037 & 0.236 \\
\hline
\end{tabular}




\section{TABLE 5 \\ Auditor Style and the Effect of Tenure \\ Letter-Pairs Sample}

This table presents tests of $\mathrm{H} 2$ using equation (2). Long Tenure is an indicator equal to one if both letters in the letter-pair have been with their auditor for five or more years. All other variables are defined in Appendix A. The comment letter pairing process is described in Appendix B. Tstatistics are in parentheses. $*, * *$, and $* * *$ denote statistical significance at the $\mathrm{p}<0.10, \mathrm{p}<0.05$ and $\mathrm{p}<0.01$ levels (two-tailed test), respectively. A positive (negative) coefficient on Long

Tenure in columns (1) through (3) ((4) through (6)) is consistent with clients converging (diverging) in style and deficiencies as auditor tenure increases.

\begin{tabular}{|c|c|c|c|c|c|c|}
\hline \multirow{3}{*}{$\begin{array}{l}\text { Sample Restriction }= \\
\text { Dependent Variable }=\end{array}$} & (1) & (2) & (3) & (4) & (5) & (6) \\
\hline & \multicolumn{3}{|c|}{ Same Auditor $=1$} & \multicolumn{3}{|c|}{ Same Auditor $=0$} \\
\hline & $\begin{array}{l}\text { Similar } \\
\text { Keys }\end{array}$ & $\begin{array}{c}\text { Similar } \\
\text { Types }\end{array}$ & $\begin{array}{c}\text { Similar } \\
\text { Text }\end{array}$ & $\begin{array}{l}\text { Similar } \\
\text { Keys }\end{array}$ & $\begin{array}{c}\text { Similar } \\
\text { Types }\end{array}$ & $\begin{array}{c}\text { Similar } \\
\text { Text }\end{array}$ \\
\hline Long Tenure & $\begin{array}{l}0.010 \\
(0.13)\end{array}$ & $\begin{array}{c}0.093 \\
(1.74)^{*}\end{array}$ & $\begin{array}{c}0.109 \\
(2.02)^{* *}\end{array}$ & $\begin{array}{l}-0.088 \\
(-1.80)^{*}\end{array}$ & $\begin{array}{l}0.046 \\
(1.44)\end{array}$ & $\begin{array}{c}-0.134 \\
(-3.85)^{* * *}\end{array}$ \\
\hline Altman Z Diff & $\begin{array}{l}-0.015 \\
(-1.73)^{*}\end{array}$ & $\begin{array}{l}0.001 \\
(0.22)\end{array}$ & $\begin{array}{c}0.014 \\
(2.32)^{* *}\end{array}$ & $\begin{array}{l}-0.003 \\
(-0.61)\end{array}$ & $\begin{array}{l}-0.006 \\
(-1.57)\end{array}$ & $\begin{array}{l}0.005 \\
(1.28)\end{array}$ \\
\hline Altman Z Min & $\begin{array}{c}0.091 \\
(4.76)^{* * *}\end{array}$ & $\begin{array}{c}0.027 \\
(2.23)^{* *}\end{array}$ & $\begin{array}{c}0.089 \\
(6.61)^{* * * *}\end{array}$ & $(8.03)^{* * *}$ & $(3.03) * * *$ & $\begin{array}{c}0.082 \\
(10.48)^{* *} \\
*\end{array}$ \\
\hline $\begin{array}{l}\text { Concurrent Restatement } \\
\text { Diff }\end{array}$ & $\begin{array}{l}-0.204 \\
(-1.75)^{*}\end{array}$ & $\begin{array}{l}0.047 \\
(0.61)\end{array}$ & $\begin{array}{l}-0.152 \\
(-1.94)^{*}\end{array}$ & $\begin{array}{c}-0.272 \\
(-3.85)^{* * *}\end{array}$ & $\begin{array}{l}0.061 \\
(1.27)\end{array}$ & $\begin{array}{c}-0.146 \\
(-2.98) * * *\end{array}$ \\
\hline $\begin{array}{l}\text { Concurrent Restatement } \\
\text { Min }\end{array}$ & $\begin{array}{l}0.570 \\
(1.06)\end{array}$ & $\begin{array}{l}0.149 \\
(0.40)\end{array}$ & $\begin{array}{l}-0.164 \\
(-0.47)\end{array}$ & $\begin{array}{l}0.023 \\
(0.07)\end{array}$ & $\begin{array}{l}-0.123 \\
(-0.63)\end{array}$ & $\begin{array}{l}-0.398 \\
(-1.92)^{*}\end{array}$ \\
\hline Ext Financing Diff & $\begin{array}{l}0.910 \\
(1.55)\end{array}$ & $\begin{array}{l}-0.579 \\
(-1.53)\end{array}$ & $\begin{array}{c}-1.058 \\
(-2.90) * * *\end{array}$ & $\begin{array}{l}-0.458 \\
(-1.29)\end{array}$ & $\begin{array}{l}-0.182 \\
(-0.78)\end{array}$ & $\begin{array}{c}-1.013 \\
(-4.37)^{* * *}\end{array}$ \\
\hline Ext Financing Min & $\begin{array}{l}-0.504 \\
(-0.64)\end{array}$ & $\begin{array}{l}-0.639 \\
(-1.29)\end{array}$ & $\begin{array}{l}0.306 \\
(0.59)\end{array}$ & $\begin{array}{c}-0.985 \\
(-2.13)^{* *}\end{array}$ & $\begin{array}{c}-0.614 \\
(-2.07)^{* *}\end{array}$ & $\begin{array}{c}-1.028 \\
(-2.27)^{* *}\end{array}$ \\
\hline Filings Diff & $\begin{array}{l}0.061 \\
(1.44)\end{array}$ & $\begin{array}{c}-0.535 \\
(-20.07) * * *\end{array}$ & $\begin{array}{c}-1.056 \\
(- \\
37.46) * * *\end{array}$ & 0.160 & $\begin{array}{c}-0.567 \\
(-35.85)^{* * *}\end{array}$ & $\begin{array}{c}-1.011 \\
(- \\
51.49) * * *\end{array}$ \\
\hline Filings Min & $\begin{array}{c}3.070 \\
(43.51)^{* * *}\end{array}$ & $\begin{array}{c}-0.355 \\
(-9.26)^{* * *}\end{array}$ & $\begin{array}{c}-0.218 \\
(-4.91)^{* * *}\end{array}$ & $\begin{array}{c}2.874 \\
(68.05)^{* * *}\end{array}$ & $\begin{array}{c}-0.413 \\
(-17.60)^{* * *}\end{array}$ & $\begin{array}{c}-0.273 \\
*(-9.21) * * *\end{array}$ \\
\hline Firm Age Diff & $\begin{array}{l}-0.001 \\
(-0.26)\end{array}$ & $\begin{array}{l}0.003 \\
(1.38)\end{array}$ & $\begin{array}{c}-0.008 \\
(-4.01)^{* * *}\end{array}$ & $\begin{array}{c}-0.004 \\
(-2.28)^{* *}\end{array}$ & $\begin{array}{l}-0.000 \\
(-0.24)\end{array}$ & $\begin{array}{c}-0.007 \\
(-5.44)^{* * *}\end{array}$ \\
\hline Firm Age Min & $(5.85) * * *$ & $(4.68) * * *$ & $(7.71) * * *$ & $(9.82)^{* * *}$ & $(5.40) * * *$ & $\begin{array}{c}0.030 \\
(15.22)^{* *} \\
*\end{array}$ \\
\hline High Volatility Diff & $\begin{array}{c}0.429 \\
(5.20)^{* * *}\end{array}$ & $\begin{array}{l}-0.046 \\
(-0.88)\end{array}$ & $\begin{array}{c}-0.202 \\
(-3.70)^{* * *}\end{array}$ & $\begin{array}{c}0.189 \\
(3.87)^{* * *}\end{array}$ & $\begin{array}{l}0.043 \\
(1.36)\end{array}$ & $\begin{array}{c}-0.201 \\
(-5.52)^{* * *}\end{array}$ \\
\hline High Volatility Min & $\begin{array}{c}0.853 \\
(4.99)^{* * *}\end{array}$ & $\begin{array}{l}0.082 \\
(0.76)\end{array}$ & $\begin{array}{l}-0.210 \\
(-1.81)^{*}\end{array}$ & $\begin{array}{c}0.457 \\
(4.57)^{* * *}\end{array}$ & $\begin{array}{c}0.234 \\
(3.54)^{* * *}\end{array}$ & $\begin{array}{c}-0.332 \\
(-5.03) * * *\end{array}$ \\
\hline ICMW Diff & $\begin{array}{c}-1.351 \\
(-9.23) * * *\end{array}$ & $(-11.61)^{* * *}$ & $(-4.88) * * *$ & $\begin{array}{c}-1.491 \\
(- \\
17.67)^{* * *}\end{array}$ & $(-22.29) * *$ & $*(-9.44) * * *$ \\
\hline ICMW Min & $\begin{array}{l}-0.591 \\
(-0.80)\end{array}$ & $\begin{array}{c}-0.992 \\
(-1.80)^{*}\end{array}$ & $\begin{array}{l}-0.546 \\
(-1.12)\end{array}$ & $\begin{array}{c}-1.952 \\
(-4.42)^{* * *}\end{array}$ & $\begin{array}{c}-2.267 \\
(-9.84) * * *\end{array}$ & $\begin{array}{c}-0.807 \\
(-2.95)^{* * *}\end{array}$ \\
\hline
\end{tabular}




\begin{tabular}{|c|c|c|c|c|c|c|}
\hline Litigation Risk Diff & $(-7.19) * * *$ & $(-2.52)^{* *}$ & $(-6.98) * * *$ & $\begin{array}{c}-0.814 \\
(- \\
10.86)^{* * *}\end{array}$ & $(-6.25)^{* * *}$ & $\begin{array}{c}-0.590 \\
(- \\
11.47)^{* * *}\end{array}$ \\
\hline \multirow[t]{2}{*}{ Litigation Risk Min } & 0.223 & 0.651 & $\begin{array}{c}2.307 \\
(19.28)^{* *}\end{array}$ & 0.181 & 0.621 & $\begin{array}{c}2.433 \\
(33.47)^{* *}\end{array}$ \\
\hline & $(1.30)$ & $(6.19) * * *$ & $*$ & $(1.80)^{*}$ & $(9.77)^{* * *}$ & $*$ \\
\hline \multirow[t]{2}{*}{ LnMV Diff } & $\begin{array}{c}-0.462 \\
(-\end{array}$ & -0.143 & $\begin{array}{c}-0.337 \\
(-\end{array}$ & $\begin{array}{c}-0.456 \\
(-\end{array}$ & -0.156 & $\begin{array}{c}-0.324 \\
(-\end{array}$ \\
\hline & $14.98) * * *$ & $(-7.29)^{* * *}$ & $16.16) * * *$ & $24.54) * * *$ & $(-13.06)^{* * *}$ & $* 22.99$ )*** \\
\hline \multirow[t]{2}{*}{ LnMV Min } & -0.323 & -0.116 & -0.139 & $\begin{array}{c}-0.281 \\
(-\end{array}$ & -0.141 & -0.162 \\
\hline & $(-7.91) * * *$ & $(-4.59) * * *$ & $(-4.69) * * *$ & $11.83)^{* * *}$ & $(-9.19)^{* * *}$ & $(-8.03) * * *$ \\
\hline \multirow[t]{2}{*}{ Loss Diff } & 0.419 & -0.384 & -0.399 & 0.355 & -0.294 & -0.444 \\
\hline & $(4.12)^{* * *}$ & $(-6.22)^{* * *}$ & $(-5.98) * * *$ & $(5.87)^{* * *}$ & $(-7.72)^{* * *}$ & $(-9.93) * * *$ \\
\hline \multirow[t]{2}{*}{ Loss Min } & 0.182 & -0.419 & -0.752 & 0.584 & -0.270 & -0.594 \\
\hline & $(0.91)$ & $(-3.43) * * *$ & $(-5.61) * * *$ & $(4.81) * * *$ & $(-3.67) * * *$ & $(-7.27)^{* * *}$ \\
\hline \multirow[t]{2}{*}{ MNA Diff } & -0.304 & -0.322 & -0.411 & -0.205 & -0.230 & -0.266 \\
\hline & $(-3.30) * * *$ & $(-5.41) * * *$ & $(-6.79) * * *$ & $(-3.71) * * *$ & $(-6.30) * * *$ & $(-6.33) * * *$ \\
\hline \multirow[t]{2}{*}{ MNA Min } & -0.084 & -0.453 & -0.412 & 0.050 & -0.352 & -0.228 \\
\hline & $(-0.72)$ & $(-6.31) * * *$ & $(-5.31) * * *$ & $(0.74)$ & $(-8.14)^{* * *}$ & $(-4.78) * * *$ \\
\hline \multirow[t]{2}{*}{ Restructure Diff } & -0.034 & 0.002 & -0.403 & -0.077 & -0.048 & -0.331 \\
\hline & $(-0.38)$ & $(0.03)$ & $(-6.70)^{* * *}$ & $(-1.45)$ & $(-1.41)$ & $(-8.10) * * *$ \\
\hline \multirow[t]{2}{*}{ Restructure Min } & 0.514 & 0.197 & 0.056 & 0.465 & 0.193 & 0.049 \\
\hline & $(3.94) * * *$ & $(2.38) * *$ & $(0.61)$ & $(6.07) * * *$ & $(3.92)^{* * *}$ & $(0.93)$ \\
\hline \multirow[t]{2}{*}{ ROA Diff } & -3.953 & -0.933 & -2.379 & -3.861 & -0.289 & -2.113 \\
\hline & $(-7.45) * * *$ & $(-2.69) * * *$ & $(-6.62)^{* * *}$ & $12.14)^{* * *}$ & $(-1.34)$ & $(-8.86)^{* * *}$ \\
\hline \multirow[t]{2}{*}{ ROA Min } & -3.760 & -1.742 & -2.370 & -3.502 & -1.039 & -2.407 \\
\hline & $(-6.46) * * *$ & $(-4.62)^{* * *}$ & $(-6.03) * * *$ & $(-9.95) * * *$ & $(-4.37) * * *$ & $(-9.44) * * *$ \\
\hline \multirow[t]{2}{*}{ Sales Growth Diff } & -0.349 & 0.089 & -0.358 & -0.332 & -0.008 & -0.515 \\
\hline & $(-3.53) * * *$ & $(1.42)$ & $(-5.76) * * *$ & $(-5.70) * * *$ & $(-0.21)$ & $13.59)^{* * *}$ \\
\hline \multirow[t]{2}{*}{ Sales Growth Min } & 0.329 & 0.925 & 0.696 & 0.772 & 0.753 & 0.718 \\
\hline & $(1.69)^{*}$ & $(6.61)^{* * *}$ & $(5.40) * * *$ & $(6.45)^{* * *}$ & $(9.13) * * *$ & $(8.76)^{* * *}$ \\
\hline \multirow[t]{2}{*}{ Segments Diff } & -0.155 & 0.030 & 0.010 & -0.057 & 0.045 & -0.003 \\
\hline & $(-4.84) * * *$ & $(1.42)$ & $(0.46)$ & $(-3.05) * * *$ & $(3.61)^{* * *}$ & $(-0.24)$ \\
\hline \multirow[t]{2}{*}{ Segments Min } & -0.187 & 0.057 & 0.091 & -0.071 & 0.056 & 0.038 \\
\hline & $(-3.30) * * *$ & $(1.59)$ & $(2.12)^{* *}$ & $(-2.24)^{* *}$ & $(2.70)^{* * *}$ & $(1.80)^{*}$ \\
\hline \multirow[t]{3}{*}{ Constant } & 7.534 & 12.347 & 63.056 & 3.923 & 10.098 & 60.996 \\
\hline & & & $(52.80)^{* *}$ & & & $(75.51)^{* *}$ \\
\hline & $(3.04) * * *$ & $(12.85)^{* * *}$ & $*$ & $(1.58)$ & $(13.75)^{* * * *}$ & $*$ \\
\hline $\begin{array}{l}\text { Industry and Year Fixed } \\
\text { Effects }\end{array}$ & Y & $\mathrm{Y}$ & Y & $\mathrm{Y}$ & $\mathrm{Y}$ & $\mathrm{Y}$ \\
\hline Robust Standard Errors & & & & & & \\
\hline $\begin{array}{l}\text { Clustered by Unique Gvkey } \\
\text { Pair }\end{array}$ & $\mathrm{Y}$ & $\mathrm{Y}$ & Y & Y & $\mathrm{Y}$ & $\mathrm{Y}$ \\
\hline Observations & 66,911 & 66,911 & 66,115 & 180,871 & 180,871 & 178,294 \\
\hline $\mathrm{R}^{2}$ & 0.086 & 0.038 & 0.266 & 0.080 & 0.038 & 0.227 \\
\hline Adjusted $\mathrm{R}^{2}$ & 0.084 & 0.037 & 0.264 & 0.080 & 0.037 & 0.227 \\
\hline
\end{tabular}




\section{TABLE 6 \\ Auditor Changes and Assuming Disclosure Deficiencies Switching Letter-Pairs Sample}

This table presents tests of $\mathrm{H} 3$ using equation (3), the modified letter-pairs sample and the three measures of comment letter similarity. All variables are defined in Appendix A. Each pair contains one letter for a client that changed auditors between comment letters and one letter for a client that never changed auditors. The selection and pairing of changing and nonchanging letters is described in Appendix C. T-statistics are in parentheses. $*, * *$, and $* * *$ denote statistical significance at the $\mathrm{p}<0.10, \mathrm{p}<0.05$ and $\mathrm{p}$ $<0.01$ levels (two-tailed test), respectively. A positive coefficient on Switch is consistent with clients assuming the deficiencies of a new auditor after switching as measured by comment letters that are more similar to the subsequent auditor's existing clients.

\begin{tabular}{|c|c|c|c|}
\hline Dependent Variable $=$ & $\begin{array}{c}\text { (1) } \\
\text { Similar Keys }\end{array}$ & $\begin{array}{c}(2) \\
\text { Similar Types }\end{array}$ & $\begin{array}{c}(3) \\
\text { Similar Text }\end{array}$ \\
\hline Switch & $\begin{array}{c}1.314 \\
(3.40)^{* * *}\end{array}$ & $\begin{array}{c}0.516 \\
(2.33)^{* *}\end{array}$ & $\begin{array}{c}0.914 \\
(2.46)^{* *}\end{array}$ \\
\hline Altman Z Diff & $\begin{array}{l}0.023 \\
(0.88)\end{array}$ & $\begin{array}{l}0.025 \\
(1.20)\end{array}$ & $\begin{array}{c}-0.046 \\
(-1.96)^{*}\end{array}$ \\
\hline Altman Z Min & $\begin{array}{l}0.062 \\
(1.05)\end{array}$ & $\begin{array}{c}0.133 \\
(3.20)^{* * *}\end{array}$ & $\begin{array}{c}0.138 \\
(2.80)^{* * *}\end{array}$ \\
\hline Auditor Tenure Diff & $\begin{array}{l}0.057 \\
(1.21)\end{array}$ & $\begin{array}{c}0.085 \\
(2.71)^{* * *}\end{array}$ & $\begin{array}{c}0.078 \\
(1.81)^{*}\end{array}$ \\
\hline Auditor Tenure Min & $\begin{array}{l}0.046 \\
(0.71)\end{array}$ & $\begin{array}{l}-0.015 \\
(-0.35)\end{array}$ & $\begin{array}{l}0.039 \\
(0.66)\end{array}$ \\
\hline Concurrent Restatement Diff & $\begin{array}{c}-0.604 \\
(-1.98)^{* *}\end{array}$ & $\begin{array}{l}-0.252 \\
(-1.20)\end{array}$ & $\begin{array}{l}-0.092 \\
(-0.32)\end{array}$ \\
\hline Concurrent Restatement Min & $\begin{array}{l}-1.357 \\
(-1.23)\end{array}$ & $\begin{array}{l}0.250 \\
(0.24)\end{array}$ & $\begin{array}{l}-0.318 \\
(-0.25)\end{array}$ \\
\hline Ext Financing Diff & $\begin{array}{l}-0.013 \\
(-0.01)\end{array}$ & $\begin{array}{l}1.963 \\
(1.50)\end{array}$ & $\begin{array}{c}3.033 \\
(2.25)^{* *}\end{array}$ \\
\hline Ext Financing Min & $\begin{array}{l}0.318 \\
(0.13)\end{array}$ & $\begin{array}{l}1.699 \\
(0.95)\end{array}$ & $\begin{array}{c}6.938 \\
(3.47)^{* * *}\end{array}$ \\
\hline Filings Diff & $\begin{array}{l}0.016 \\
(0.12)\end{array}$ & $\begin{array}{c}-0.635 \\
(-7.99) * * *\end{array}$ & $\begin{array}{c}-1.047 \\
(-8.80)^{* * *}\end{array}$ \\
\hline Filings Min & $\begin{array}{c}2.687 \\
(12.77)^{* * *}\end{array}$ & $\begin{array}{c}-0.616 \\
(-5.19)^{* * * *}\end{array}$ & $\begin{array}{c}-0.419 \\
(-2.20)^{* *}\end{array}$ \\
\hline Firm Age Diff & $\begin{array}{l}0.002 \\
(0.19)\end{array}$ & $\begin{array}{l}-0.004 \\
(-0.75)\end{array}$ & $\begin{array}{l}-0.007 \\
(-0.84)\end{array}$ \\
\hline Firm Age Min & $\begin{array}{c}0.036 \\
(2.61)^{* * *}\end{array}$ & $\begin{array}{l}0.007 \\
(0.79)\end{array}$ & $\begin{array}{c}0.039 \\
(3.24)^{* * *}\end{array}$ \\
\hline High Volatility Diff & $\begin{array}{l}-0.357 \\
(-1.41)\end{array}$ & $\begin{array}{l}-0.110 \\
(-0.63)\end{array}$ & $\begin{array}{l}-0.281 \\
(-1.19)\end{array}$ \\
\hline High Volatility Min & $\begin{array}{c}-0.822 \\
(-1.73)^{*}\end{array}$ & $\begin{array}{c}-0.939 \\
(-3.05)^{* * * *}\end{array}$ & $\begin{array}{c}-0.757 \\
(-1.76)^{*}\end{array}$ \\
\hline ICMW Diff & $\begin{array}{c}-0.833 \\
(-2.29)^{* *}\end{array}$ & $\begin{array}{c}-1.044 \\
(-4.31)^{* * *}\end{array}$ & $\begin{array}{c}-0.730 \\
(-2.18)^{* *}\end{array}$ \\
\hline ICMW Min & $\begin{array}{l}0.403 \\
(0.23)\end{array}$ & $\begin{array}{l}-1.243 \\
(-1.94)^{*}\end{array}$ & $\begin{array}{l}-2.287 \\
(-1.67)^{*}\end{array}$ \\
\hline
\end{tabular}




\begin{tabular}{|c|c|c|c|}
\hline Litigation Risk Diff & $\begin{array}{l}-0.330 \\
(-0.71)\end{array}$ & $\begin{array}{c}0.704 \\
(2.41)^{* *}\end{array}$ & $\begin{array}{l}-0.225 \\
(-0.52)\end{array}$ \\
\hline \multirow[t]{2}{*}{ Litigation Risk Min } & 0.399 & 1.568 & 2.988 \\
\hline & $(0.67)$ & $(4.48)^{* * *}$ & $(5.63) * * *$ \\
\hline \multirow[t]{2}{*}{ LnMV Diff } & -0.474 & -0.256 & -0.355 \\
\hline & $(-4.91) * * *$ & $(-4.12) * * *$ & $(-3.81) * * *$ \\
\hline \multirow[t]{2}{*}{ LnMV Min } & -0.212 & -0.376 & -0.293 \\
\hline & $(-1.70)^{*}$ & $(-4.56) * * *$ & $(-2.56)^{* *}$ \\
\hline \multirow[t]{2}{*}{ Loss Diff } & 0.360 & -0.432 & 0.209 \\
\hline & $(1.22)$ & $(-2.26)^{* *}$ & $(0.78)$ \\
\hline \multirow[t]{2}{*}{ Loss Min } & -0.861 & -1.145 & -0.061 \\
\hline & $(-1.50)$ & $(-3.34)^{* * *}$ & $(-0.11)$ \\
\hline \multirow[t]{2}{*}{ MNA Diff } & -0.125 & -0.261 & -0.070 \\
\hline & $(-0.47)$ & $(-1.53)$ & $(-0.31)$ \\
\hline \multirow[t]{2}{*}{ MNA Min } & -0.557 & -0.161 & -0.617 \\
\hline & $(-1.60)$ & $(-0.70)$ & $(-2.03)^{* *}$ \\
\hline \multirow[t]{2}{*}{ Restructure Diff } & -0.139 & 0.298 & -0.223 \\
\hline & $(-0.51)$ & $(1.72)^{*}$ & $(-0.90)$ \\
\hline \multirow[t]{2}{*}{ Restructure Min } & 0.832 & 0.270 & 0.160 \\
\hline & $(2.05)^{* *}$ & $(1.07)$ & $(0.40)$ \\
\hline \multirow[t]{2}{*}{ ROA Diff } & -3.709 & -2.007 & -2.085 \\
\hline & $(-2.09)^{* *}$ & $(-1.66)^{*}$ & $(-1.21)$ \\
\hline \multirow[t]{2}{*}{ ROA Min } & -2.272 & -2.569 & -2.966 \\
\hline & $(-1.20)$ & $(-2.01)^{* *}$ & $(-1.64)$ \\
\hline \multirow[t]{2}{*}{ Sales Growth Diff } & 0.678 & 0.358 & -0.660 \\
\hline & $(2.03) * *$ & $(1.58)$ & $(-2.08)^{* *}$ \\
\hline \multirow[t]{2}{*}{ Sales Growth Min } & 1.607 & -0.198 & 0.788 \\
\hline & $(2.53)^{* *}$ & $(-0.52)$ & $(1.42)$ \\
\hline \multirow[t]{2}{*}{ Segments Diff } & -0.309 & 0.131 & 0.129 \\
\hline & $(-3.47)^{* * *}$ & $(2.03)^{* *}$ & $(1.43)$ \\
\hline \multirow[t]{2}{*}{ Segments Min } & 0.034 & 0.234 & 0.338 \\
\hline & $(0.23)$ & $(2.29) * *$ & $(2.29) * *$ \\
\hline \multirow[t]{2}{*}{ Constant } & 5.131 & 12.311 & 70.154 \\
\hline & $(2.38)^{* *}$ & $(6.02)^{* * *}$ & $(16.27)^{* * *}$ \\
\hline Industry and Year Fixed Effects & $\mathrm{Y}$ & $\mathrm{Y}$ & $\mathrm{Y}$ \\
\hline \multicolumn{4}{|l|}{ Robust Standard Errors } \\
\hline \multicolumn{4}{|l|}{ Letter-Pair } \\
\hline Observations & 7,307 & 7,307 & 3,554 \\
\hline $\mathrm{R}^{2}$ & 0.085 & 0.076 & 0.293 \\
\hline Adjusted $\mathrm{R}^{2}$ & 0.074 & 0.065 & 0.276 \\
\hline
\end{tabular}




\section{TABLE 7}

\section{Auditor Style and SEC Comment Letter Similarity by Issue Type Letter-Pairs Sample}

This table presents tests of $\mathrm{H} 1$ using equation (1), the letter-pairs sample, and the six sub measures of Similar Keys categorized by type. Each dependent variable is analogous to Similar Keys except that only issues from a particular issue type are counted. The sample is restricted to those letters that have at least one issue key noted for a particular type. Coefficients on Same Auditor have been standardized to facilitate comparisons across models. All other variables are defined in Appendix A. The comment letter pairing process is described in Appendix B. T-statistics are in parentheses. *, **, *** denote statistical significance at the $\mathrm{p}<0.10, \mathrm{p}<0.05$ and $\mathrm{p}<0.01$ levels (two-tailed test), respectively. A positive coefficient on Same Auditor is consistent with auditor style manifesting in common disclosure deficiencies as measured by more similar comment letters for a particular type of issue.

\begin{tabular}{|c|c|c|c|c|c|c|}
\hline Issue Type $=$ & $\begin{array}{c}(1) \\
\text { Accounting } \\
\text { Rule }\end{array}$ & $\begin{array}{c}(2) \\
M D \& A\end{array}$ & $\begin{array}{c}\text { (3) } \\
\text { Internal } \\
\text { Control }\end{array}$ & $\begin{array}{c}\text { (4) } \\
\text { Risk } \\
\text { Factor }\end{array}$ & $\begin{array}{c}\text { (5) } \\
\text { Regulatory } \\
\text { Filing }\end{array}$ & $\begin{array}{c}\text { (6) } \\
\text { Other }\end{array}$ \\
\hline Same Auditor & $\begin{array}{c}0.006 \\
(2.30)^{* *}\end{array}$ & $\begin{array}{c}0.007 \\
(2.59) * * *\end{array}$ & $\begin{array}{l}-0.048 \\
(-1.41)\end{array}$ & $\begin{array}{l}-0.015 \\
(-1.07)\end{array}$ & $\begin{array}{l}-0.019 \\
(-1.30)\end{array}$ & $\begin{array}{c}0.005 \\
(1.99)^{* *}\end{array}$ \\
\hline Controls & $\mathrm{Y}$ & $\mathrm{Y}$ & $\mathrm{Y}$ & $\mathrm{Y}$ & $\mathrm{Y}$ & $\mathrm{Y}$ \\
\hline $\begin{array}{l}\text { Industry and Year Fixed Effects } \\
\text { Robust Standard Errors }\end{array}$ & Y & Y & Y & Y & Y & Y \\
\hline $\begin{array}{l}\text { Clustered by Unique Gvkey } \\
\text { Pair }\end{array}$ & Y & Y & Y & Y & Y & Y \\
\hline Observations & 163,399 & 119,117 & 832 & 4,772 & 4,333 & 165,463 \\
\hline $\mathrm{R}^{2}$ & 0.090 & 0.056 & 0.239 & 0.142 & 0.090 & 0.098 \\
\hline Adjusted $\mathrm{R}^{2}$ & 0.089 & 0.055 & 0.166 & 0.127 & 0.070 & 0.098 \\
\hline
\end{tabular}




\section{TABLE 8 \\ Comment Letter Similarity and the Self-Fulfilling Prophecy \\ Comment Letter Sample}

This table presents tests of the temporal version of the self-fulfilling prophecy using logistic estimations of equation (4) and the comment letter sample. The dependent variable is an indicator equal to one if the comment letter had at least one issue key noted for a particular issue type. Prior Issue Auditor is an indicator equal to one if another client with the same industry and with the same auditor had a letter with at least one issue key noted for that type in the prior 365 days. All other variables are defined in Appendix A. T-statistics are in parentheses. *, **, and $* * *$ denote statistical significance at the $\mathrm{p}<0.10, \mathrm{p}<0.05$ and $\mathrm{p}<0.01$ levels (two-tailed test), respectively. A positive coefficient on Prior Issue Auditor is consistent with SEC comment letter reviewers being more likely to identify an issue for a particular type if another client with the same industry and auditor had an issue of that type in the previous 365 days.

\begin{tabular}{lcccccc}
\hline & $\begin{array}{c}(1) \\
\text { Accounting } \\
\text { Issue Type }\end{array}$ & $\begin{array}{c}(2) \\
\text { Rule }\end{array}$ & $\begin{array}{c}\text { (3) } \\
\text { Internal } \\
\text { Control }\end{array}$ & $\begin{array}{c}(4) \\
\text { Risk } \\
\text { Factor }\end{array}$ & $\begin{array}{c}(5) \\
\text { Regulatory } \\
\text { Filing }\end{array}$ & Other \\
\hline Prior Issue Auditor & 0.390 & 0.110 & -0.032 & -0.009 & -0.227 & -0.755 \\
& $(0.82)$ & $(0.46)$ & $(-0.18)$ & $(-0.06)$ & $(-1.61)$ & $(-1.81)^{*}$ \\
\hline Controls & $\mathrm{Y}$ & $\mathrm{Y}$ & $\mathrm{Y}$ & $\mathrm{Y}$ & $\mathrm{Y}$ & $\mathrm{Y}$ \\
Industry and Year Fixed Effects & $\mathrm{Y}$ & $\mathrm{Y}$ & $\mathrm{Y}$ & $\mathrm{Y}$ & $\mathrm{Y}$ & $\mathrm{Y}$ \\
Robust Standard Errors & $\mathrm{Y}$ & $\mathrm{Y}$ & $\mathrm{Y}$ & $\mathrm{Y}$ & $\mathrm{Y}$ & $\mathrm{Y}$ \\
Clustered by Gvkey & 9,610 & 10,058 & 8,212 & 9,728 & 9,466 & 9,436 \\
Observations & 0.334 & 0.153 & 0.174 & 0.153 & 0.151 & 0.194 \\
Pseudo R & & & & & &
\end{tabular}




\section{TABLE 9}

\section{Auditor Style for Non-Big 4 Clients}

\section{Letter-Pairs Sample for Non-Big 4 Clients}

This table presents tests of the intuition that the association between auditor style and common disclosure deficiencies should be weaker among Non-Big 4 audit firms. These tests use equation (1) and a letter-pairs sample constructed using Non-Big 4 clients that received SEC comment letters. All variables are defined in Appendix A. The comment letter pairing process is described in Appendix B. Tstatistics are in parentheses. *, **, and $* * *$ denote statistical significance at the $\mathrm{p}<0.10, \mathrm{p}<0.05$ and $\mathrm{p}<0.01$ levels (two-tailed test), respectively. A positive coefficient on Same Auditor is consistent with auditor style manifesting in common disclosure deficiencies as measured by more similar comment letters.

\begin{tabular}{lccc}
\hline Dependent Variable & $\begin{array}{c}(1) \\
\text { Similar } \\
\text { Keys }\end{array}$ & $\begin{array}{c}(2) \\
\text { Similar } \\
\text { Types }\end{array}$ & $\begin{array}{c}\text { Similar } \\
\text { Text }\end{array}$ \\
\hline Same Auditor & $\begin{array}{c}-0.517 \\
(-1.76)^{*}\end{array}$ & $\begin{array}{c}0.129 \\
(0.73)\end{array}$ & $\begin{array}{c}0.458 \\
(2.57)^{* *}\end{array}$ \\
\hline Controls & $\mathrm{Y}$ & $\mathrm{Y}$ & $\mathrm{Y}$ \\
$\begin{array}{l}\text { Industry and Year Fixed } \\
\text { Effects }\end{array}$ & $\mathrm{Y}$ & $\mathrm{Y}$ & $\mathrm{Y}$ \\
$\begin{array}{l}\text { Robust Standard Errors } \\
\text { Clustered by Unique Gvkey }\end{array}$ & $\mathrm{Y}$ & $\mathrm{Y}$ & $\mathrm{Y}$ \\
Pair & & & \\
\hline Observations & 9,710 & 9,710 & 9,494 \\
$\mathrm{R}^{2}$ & 0.207 & 0.121 & 0.287 \\
Adjusted $\mathrm{R}^{2}$ & 0.200 & 0.114 & 0.280 \\
\hline
\end{tabular}




\section{TABLE 10 \\ Auditor Style and Overall Disclosure Quality \\ Full Compustat and Comment Letter Samples}

This table presents tests of whether overall disclosure quality, as measured by receipt of and/or more severe SEC comment letters, is different among the Big 4 clienteles. Columns (1) and (2) use equations (5a) and the full Compustat sample of Big 4 clients. Columns (3) through (10) use equations (6a) and (6b) and the comment letter sample from Table 2 Panel A. All variables are defined in Appendix A. A statistically significant $\mathrm{Chi}^{2} / \mathrm{F}$ statistic for the audit firm fixed effects is consistent with different levels of overall disclosure quality among the Big 4 firms.

\begin{tabular}{|c|c|c|c|c|c|c|c|c|c|c|}
\hline \multirow{3}{*}{$\begin{array}{l}\text { Sample }= \\
\text { Dependent Variable = }\end{array}$} & (1) & (2) & (3) & (4) & (5) & (6) & (7) & (8) & (9) & (10) \\
\hline & \multirow{2}{*}{\multicolumn{2}{|c|}{$\begin{array}{c}\text { Full Compustat } \\
\text { Letter }\end{array}$}} & \multicolumn{8}{|c|}{ Comment Letter } \\
\hline & & & \multicolumn{2}{|c|}{ Keys } & \multicolumn{2}{|c|}{ Types } & \multicolumn{2}{|c|}{ Rounds } & \multicolumn{2}{|c|}{ Days } \\
\hline Controls & $\mathrm{Y}$ & $\mathrm{Y}$ & $\mathrm{Y}$ & $\mathrm{Y}$ & $\mathrm{Y}$ & $\mathrm{Y}$ & $\mathrm{Y}$ & $\mathrm{Y}$ & $\mathrm{Y}$ & $\mathrm{Y}$ \\
\hline $\begin{array}{l}\text { Industry and Year Fixed } \\
\text { Effects }\end{array}$ & Y & Y & $\mathrm{Y}$ & Y & $\mathrm{Y}$ & $\mathrm{Y}$ & Y & $\mathrm{Y}$ & Y & $\mathrm{Y}$ \\
\hline Audit Firm Fixed Effects & $\mathrm{N}$ & Y & $\mathrm{N}$ & Y & $\mathrm{N}$ & Y & $\mathrm{N}$ & Y & $\mathrm{N}$ & Y \\
\hline $\begin{array}{l}\text { Robust Standard Errors } \\
\text { Clustered by Unique } \\
\text { Gvkey Pair }\end{array}$ & Y & Y & $\mathrm{Y}$ & $\mathrm{Y}$ & $\mathrm{Y}$ & $\mathrm{Y}$ & Y & Y & Y & $\mathrm{Y}$ \\
\hline Observations & 28,290 & 28,290 & 10,536 & 10,536 & 10,536 & 10,536 & 10,536 & 10,536 & 10,536 & 10,536 \\
\hline $\mathrm{R}^{2}$ & & & 0.205 & 0.206 & 0.136 & 0.136 & 0.068 & 0.069 & 0.098 & 0.099 \\
\hline Adjusted $\mathrm{R}^{2}$ & & & 0.198 & 0.198 & 0.129 & 0.129 & 0.060 & 0.060 & 0.090 & 0.091 \\
\hline Pseudo $\mathrm{R}^{2}$ & 0.061 & 0.061 & & & & & & & & \\
\hline $\begin{array}{l}\text { Chi }^{2} \text { / F Stat for Auditor } \\
\text { Fixed Effect }\end{array}$ & 4. & 07 & & 53 & & 36 & & 75 & 2. & 84 \\
\hline P Value & 0.2 & 54 & & 662 & 0.7 & 779 & & 523 & 0.0 & 37 \\
\hline
\end{tabular}




\section{TABLE 11 \\ Auditor Style and Client Sophistication and Importance \\ Letter-Pairs Sample}

This table presents tests of the intuition that the association between auditor style and common disclosure deficiencies may vary with client sophistication and/or importance. These tests use equation (1) and subsamples of the letter-pairs sample split on proxies for sophistication and importance. In Panel A, client sophistication is proxied by above/below median levels of client total assets. In Panel B, client importance is proxied by above/below median percentage of a client audit fees to total audit fees for the client's audit office. In Panel C, client importance is proxied by above/below median percentage of a client non-audit fees to total non-audit fees for

the client's audit office. In Panel D, client importance is proxied by above/below median percentage of a client total fees to total fees for the client's audit office. All variables are defined in Appendix A. The comment letter pairing process is described in Appendix B. T-statistics are in parentheses. $*, * *, * * *$ denote statistical significance at the $\mathrm{p}<0.10, \mathrm{p}<0.05$ and $\mathrm{p}<0.01$ levels (two-tailed test), respectively. A positive coefficient on Same Auditor is consistent with auditor style manifesting in common disclosure deficiencies as measured by more similar comment letters.

Panel A: Total Assets

(1) (2)

Above Median

Sample Restriction $=$

Dependent Variable $=$

Same Auditor

Controls

Industry and Year Fixed

Effects

Robust Standard Errors

Clustered by Unique

Gvkey Pair

Observations

$\mathrm{R}^{2}$

Adjusted R ${ }^{2}$

Panel B: Percentage of Office Audit Fees

\begin{tabular}{|c|c|c|c|c|c|c|}
\hline & (1) & (2) & (3) & (4) & (5) & (6) \\
\hline Sample Restriction $=$ & \multicolumn{3}{|c|}{ Above Median } & \multicolumn{3}{|c|}{ Below Median } \\
\hline Dependent Variable $=$ & $\begin{array}{c}\text { Similar } \\
\text { Keys }\end{array}$ & $\begin{array}{l}\text { Similar } \\
\text { Types }\end{array}$ & $\begin{array}{c}\text { Similar } \\
\text { Text }\end{array}$ & $\begin{array}{l}\text { Similar } \\
\text { Keys }\end{array}$ & $\begin{array}{l}\text { Similar } \\
\text { Types }\end{array}$ & $\begin{array}{c}\text { Similar } \\
\text { Text }\end{array}$ \\
\hline Same Auditor & $\begin{array}{l}0.172 \\
(1.87)^{*}\end{array}$ & $\begin{array}{c}0.201 \\
(3.31)^{* * *}\end{array}$ & $\begin{array}{c}0.249 \\
(3.80)^{* * *} \\
\end{array}$ & $\begin{array}{c}0.291 \\
(3.61)^{* * *}\end{array}$ & $\begin{array}{l}0.036 \\
(0.70)\end{array}$ & $\begin{array}{c}0.107 \\
(2.05) * *\end{array}$ \\
\hline Controls & $\mathrm{Y}$ & $\mathrm{Y}$ & $\mathrm{Y}$ & $\mathrm{Y}$ & $\mathrm{Y}$ & $\mathrm{Y}$ \\
\hline $\begin{array}{l}\text { Industry and Year Fixed } \\
\text { Effects } \\
\text { Robust Standard Errors }\end{array}$ & Y & $\mathrm{Y}$ & $\mathrm{Y}$ & $\mathrm{Y}$ & Y & $\mathrm{Y}$ \\
\hline $\begin{array}{l}\text { Clustered by Unique } \\
\text { Gvkey Pair }\end{array}$ & Y & Y & $\mathrm{Y}$ & Y & Y & Y \\
\hline Observations & 56,841 & 56,841 & 55,582 & 71,704 & 71,704 & 71,091 \\
\hline $\mathrm{R}^{2}$ & 0.090 & 0.037 & 0.256 & 0.089 & 0.048 & 0.224 \\
\hline Adjusted $\mathrm{R}^{2}$ & 0.088 & 0.036 & 0.255 & 0.088 & 0.047 & 0.223 \\
\hline
\end{tabular}

(5) (6)

Below Median

Similar Similar Similar Similar Similar Similar

Keys Types Text Keys Types Text

$\begin{array}{llllll}0.296 & 0.137 & 0.252 & 0.088 & 0.023 & 0.073\end{array}$

\begin{tabular}{cccccc}
$(3.43)^{* * *}$ & $(2.51)^{* *}$ & $(4.29)^{* * *}$ & $(1.18)$ & $(0.50)$ & $(1.36)$ \\
\hline
\end{tabular}

$\mathrm{Y} \quad \mathrm{Y} \quad \mathrm{Y} \quad \mathrm{Y}$

Y $\quad Y$

$\mathrm{Y} \quad \mathrm{Y}$

Y

Y

$\begin{array}{llllll}\text { Y } & Y & Y & Y & Y & \text { Y }\end{array}$

\begin{tabular}{cccccc}
70,326 & 70,326 & 68,347 & 76,292 & 76,292 & 75,576 \\
0.101 & 0.036 & 0.298 & 0.083 & 0.059 & 0.183 \\
0.100 & 0.034 & 0.297 & 0.082 & 0.058 & 0.182 \\
\hline
\end{tabular}


Panel C: Percentage of Office Non Audit Fees

\begin{tabular}{|c|c|c|c|c|c|c|}
\hline \multirow{3}{*}{$\begin{array}{l}\text { Sample Restriction }= \\
\text { Dependent Variable }=\end{array}$} & (1) & (2) & (3) & (4) & (5) & (6) \\
\hline & \multicolumn{3}{|c|}{ Above Median } & \multicolumn{3}{|c|}{ Below Median } \\
\hline & $\begin{array}{c}\text { Similar } \\
\text { Keys }\end{array}$ & $\begin{array}{c}\text { Similar } \\
\text { Types }\end{array}$ & $\begin{array}{c}\text { Similar } \\
\text { Text }\end{array}$ & $\begin{array}{c}\text { Similar } \\
\text { Keys }\end{array}$ & $\begin{array}{c}\text { Similar } \\
\text { Types }\end{array}$ & $\begin{array}{c}\text { Similar } \\
\text { Text }\end{array}$ \\
\hline Same Auditor & $\begin{array}{l}0.061 \\
(0.69) \\
\end{array}$ & $\begin{array}{c}0.132 \\
(2.29)^{* *}\end{array}$ & $\begin{array}{c}0.184 \\
(2.93) * * * \\
\end{array}$ & $\begin{array}{c}0.271 \\
(3.26)^{* * *}\end{array}$ & $\begin{array}{l}-0.003 \\
(-0.06) \\
\end{array}$ & $\begin{array}{c}0.160 \\
(2.78) * * *\end{array}$ \\
\hline Controls & $\mathrm{Y}$ & $\mathrm{Y}$ & $\mathrm{Y}$ & $\mathrm{Y}$ & $\mathrm{Y}$ & $\mathrm{Y}$ \\
\hline $\begin{array}{l}\text { Industry and Year Fixed } \\
\text { Effects }\end{array}$ & Y & $\mathrm{Y}$ & $\mathrm{Y}$ & $\mathrm{Y}$ & Y & $\mathrm{Y}$ \\
\hline $\begin{array}{l}\text { Robust Standard Errors } \\
\text { Clustered by Unique } \\
\text { Gvkey Pair }\end{array}$ & Y & $\mathrm{Y}$ & $\mathrm{Y}$ & Y & Y & $\mathrm{Y}$ \\
\hline Observations & 58,644 & 58,644 & 57,230 & 67,176 & 67,176 & 66,565 \\
\hline $\mathrm{R}^{2}$ & 0.099 & 0.035 & 0.253 & 0.095 & 0.049 & 0.189 \\
\hline Adjusted $\mathrm{R}^{2}$ & 0.098 & 0.034 & 0.252 & 0.093 & 0.047 & 0.188 \\
\hline \multicolumn{7}{|c|}{ Panel D: Percentage of Office Total Fees } \\
\hline & (1) & $(2)$ & (3) & (4) & (5) & (6) \\
\hline Sample Restriction $=$ & \multicolumn{3}{|c|}{ Above Median } & \multicolumn{3}{|c|}{ Below Median } \\
\hline Dependent Variable $=$ & $\begin{array}{l}\text { Similar } \\
\text { Keys }\end{array}$ & $\begin{array}{l}\text { Similar } \\
\text { Types }\end{array}$ & $\begin{array}{c}\text { Similar } \\
\text { Text }\end{array}$ & $\begin{array}{l}\text { Similar } \\
\text { Keys }\end{array}$ & $\begin{array}{c}\text { Similar } \\
\text { Types }\end{array}$ & $\begin{array}{c}\text { Similar } \\
\text { Text }\end{array}$ \\
\hline Same Auditor & $\begin{array}{l}0.120 \\
(1.31) \\
\end{array}$ & $\begin{array}{c}0.192 \\
(3.16)^{* * *}\end{array}$ & $\begin{array}{c}0.225 \\
(3.44)^{* * *}\end{array}$ & $\begin{array}{c}0.240 \\
(3.01)^{* * *}\end{array}$ & $\begin{array}{l}0.011 \\
(0.22) \\
\end{array}$ & $\begin{array}{l}0.058 \\
(1.13)\end{array}$ \\
\hline Controls & $\mathrm{Y}$ & $\mathrm{Y}$ & $\mathrm{Y}$ & $\mathrm{Y}$ & $\mathrm{Y}$ & $\mathrm{Y}$ \\
\hline $\begin{array}{l}\text { Industry and Year Fixed } \\
\text { Effects } \\
\text { Robust Standard Errors }\end{array}$ & Y & $\mathrm{Y}$ & $\mathrm{Y}$ & $\mathrm{Y}$ & $\mathrm{Y}$ & $\mathrm{Y}$ \\
\hline $\begin{array}{l}\text { Clustered by Unique } \\
\text { Gvkey Pair }\end{array}$ & Y & $\mathrm{Y}$ & $\mathrm{Y}$ & Y & Y & $\mathrm{Y}$ \\
\hline Observations & 56,477 & 56,477 & 55,173 & 72,424 & 72,424 & 71,836 \\
\hline $\mathrm{R}^{2}$ & 0.094 & 0.036 & 0.247 & 0.090 & 0.050 & 0.228 \\
\hline Adjusted $\mathrm{R}^{2}$ & 0.092 & 0.034 & 0.246 & 0.089 & 0.049 & 0.227 \\
\hline
\end{tabular}




\section{VITA}

Matthew Baugh was born and raised in Bloomington-Normal, Illinois. He earned his bachelor and master's degrees in accounting from Illinois State University (ISU). After graduating from ISU he worked for four years at State Farm Insurance as an internal auditor and compensation analyst. While working, Matthew received his CPA license from the state of Illinois.

Matthew is married to his high school sweetheart, Jenny Baugh. The two of them have three sons together, Ryan, Evan and Nathan.

If his spare time Matthew enjoys hiking and playing board games with his family. 